NBSIR 85-3220

\title{
A Review of Energy Use Factors for Selected Household Appliances
}
J. Greenberg
B. Reeder
S. Silberstein

U.S. DEPARTMENT OF COMMERCE

National Bureau of Standards National Engineering Laboratory

Center for Building Technology

Gaithersburg, Maryland 20899

August 1985

\section{Prepared for}

U.S. Department of Energy

$-Q C$

100

.456

$85-3220$

1985 nes:-9 of Building Energy rch and Development ng Equipment Division ington, DC 20585 

1,1

\title{
A REVIEW OF ENERGY USE FACTORS
} FOR SELECTED HOUSEHOLD

\section{APPLIANCES}

\author{
J. Greenberg \\ B. Reeder \\ S. Silberstein
}

U.S. DEPARTMENT OF COMMERCE

National Bureau of Standards

National Engineering Laboratory

Center for Building Technology

Gaithersburg, Maryland 20899

August 1985

Prepared for

U.S. Department of Energy

Office of Building Energy

Research and Development

Building Equipment Division

Washington, DC 20585

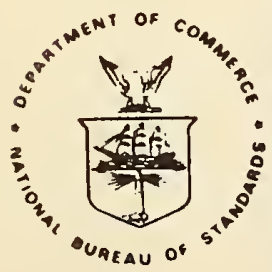

U.S. DEPARTMENT OF COMMERCE, Malcolm Baldrige, Secretary 

INIRODUCTION $\ldots \ldots \ldots \ldots \ldots \ldots \ldots \ldots \ldots \ldots \ldots \ldots \ldots \ldots \ldots \ldots \ldots \ldots$

SUMMARY OF RESULTS............................. vii

I WATER HEATER - INUET WATER TEMPERATURE................. 1-1

II WATER HEATER - OUTLET WATER TEMPERATURE................. 2-1

III WATER HEATER - AMBIENT AIR TEMPERATURE ................ 3-1

IV

$\mathrm{V}$

WATER HEATER - HOT WATER USAGE....................... 4-1

FURNACES - OUIDOOR DESIGN TEMPERATURE. ................. 5-1

FURNACES - AVERAGE ANNUAL HEATING HOURS. ............... 6-1

VI

VII

ROOM AIR CONITIONERS - YEARLY HOURS OF USE. ............. 7-1

VIII

CENIRAL AIR CONDITIONERS - ANNUAL FULL IOAD COMPRESSOR

OPERATING HOURS................................. 8-1

Figure

1-1 Median Annual Temperature of Surface Water............... I-7

$2-1$

$7-1$

Water Heater Thermostat Dials (Typical)

AHAM-Room Air Conditioner Average Compressor

Hours of Operation Per Year.......................... 7-8

8-1

Compressor Hours Per Year at $75^{\circ} \mathrm{F}$ set Point.

8-2 Compressor Hours Saved Per Year At Day Setup of

$80^{\circ}$ F From 5:00 a.m. to $4: 00$ p.m........................ 8-12

8-3 Compressor Hours Saved Per Year at a Constant

$78^{\circ} \mathrm{F}$ set point.

8-4 Distribution of Cooling Load Hours Throughout the

Continental United States.

Table

1-1 Housing Population-Weighted Average Surface Water Temperature.................................. 1-8

5-1 Housing Population-Weighted Average Outdoor Winter Percentage of U.S. Households by Inside Temperature (Single Family Residences - As of November 1982) ......... 3-9 Design Temperature.................................. 5-5

6-1 Housing Population-Weighted Average Annual Degree Days..... 6-8

7-1 Population-Weighted Average Hours of Operation for Room Air Conditioner Units........................... 7-9

8-1 Central Air Conditioner Compressor Hours Per Year at $75^{\circ} \mathrm{F}$ set Point. 
8-2 Central Air Conditioner Annual Compressor Hours of Operation at $75 \% \mathrm{~F}$ set Point Reduced to $80 \% \mathrm{~F}$ From 5:00 a.m. to $4: 00$ p.m.............................. 8-15

8-3 Central Air Conditioner Annual Compressor Hours of operation at 78\% set Polnt......................... 8-16

8-4 Central Air Conditioner Annual Full Load Compressor Hours of Operation at $75^{\circ} \mathrm{F}$ set Point.................. 8-18

8-5 National Average sumary of Alr Conditioner Annual

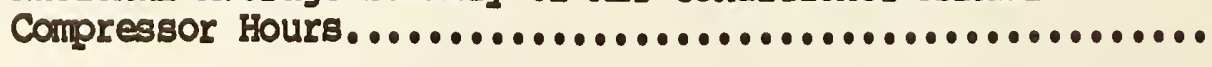




\section{INIRODUCTION}

The Energy Policy and Conservation Act (EPCA) as amended by the National Energy Conservation Policy Act (NECPA) requires the development of test procedures, labeling rules, and energy efficiency standards for consumer appliances. These requirements must be established using representative national data when establishing the various parameters for each appliance.

During the process of establishing test procedures, labeling rules, and energy efficiency standards, many of the parametric values used have been questioned through written comment and public hearings. The purpose of this report is to re-evaluate selected parametric values through analysis of current data, and provide comment and recommendations.

Each parameter reviewed is documented in an independent section in this report. As such, each section indicates the current value, the historical basis for the current value, the approach used to review and update the value, the results and conclusions, and recommendations. The recommendations generally propose a new value for the parameter studied based upon the information analyzed.

Although the parameters are treated separately, their relationships to one another is noted in each section, as applicable. For example, the delta $T$ factor for water heaters (outlet water temperature minus inlet water temperature) is an important parameter for water heater energy studies, however, the outlet and inlet temperatures are evaluated in separate sections in this report and left to the reader to relate. On the other hand, outdoor design temperature is also addressed separately, however, the results of this study are also included and used in the 
section that evaluates annual heating load hours.

Where possible, the data used to determine a recommended value are included as a table or figure in this report. This will allow the reader, if he is so inclined, to check the values selected, especially in those cases where there is a degree of subjectivity involved and there is room for individual judgement.

Finally, it should be noted that no evaluation has been made to determine the impact of any recommended revision to the currently used values on existing or proposed test procedures, energy savings, or appliance economic studies. 


\section{SLMMARY OF RESULTS}

The results of the individual studies detailed in the following sections are summarized below for easy reference.

\begin{tabular}{|c|c|c|c|}
\hline SECTION & PARAMETER STUDIED & $\begin{array}{l}\text { CURRENT } \\
\text { VALUE }\end{array}$ & $\begin{array}{l}\text { PROPOSED } \\
\text { VALUE }\end{array}$ \\
\hline I & $\begin{array}{l}\text { Water Heater - } \\
\text { Inlet Water Temperature }\end{array}$ & $55^{\circ} \mathrm{F}$ & $58^{\circ} \mathrm{F}$ \\
\hline II & $\begin{array}{l}\text { Water Heater - } \\
\text { outlet Water Temperature }\end{array}$ & $145^{\circ} \mathrm{F}$ & $135^{\circ} \mathrm{F}$ \\
\hline III & $\begin{array}{l}\text { Water Heater - } \\
\text { Ambient Air Temperature }\end{array}$ & $55^{\circ} \mathrm{F}$ & $65^{\circ} \mathrm{F}$ \\
\hline IV & $\begin{array}{l}\text { Water Heater - } \\
\text { Hot Water Usage }\end{array}$ & $\begin{array}{l}64.3 \\
\text { gal/day }\end{array}$ & $\begin{array}{l}60 \\
\text { gal/day }\end{array}$ \\
\hline V & $\begin{array}{l}\text { Furnaces - } \\
\text { Outdoor Design Temperature }\end{array}$ & ${ }^{\circ} \mathrm{F}$ & $17^{\circ} \mathrm{F}$ \\
\hline VI & $\begin{array}{l}\text { Furnaces - } \\
\text { Annual Heating Load Hours }\end{array}$ & 2080 hrs & 2080 hrs \\
\hline VII & $\begin{array}{l}\text { Room Air Conditioners - } \\
\text { Yearly Hours of Use }\end{array}$ & $\begin{array}{l}750 \\
\mathrm{hr} / \mathrm{yr}\end{array}$ & $\begin{array}{l}670 \\
\mathrm{hr} / \mathrm{yr}\end{array}$ \\
\hline VIII & $\begin{array}{l}\text { Central Air Conditioners - } \\
\text { Annual Full Load Compressor } \\
\text { operating hours }\end{array}$ & $\begin{array}{l}1000 \\
\mathrm{hr} / \mathrm{yr}\end{array}$ & $\begin{array}{l}1150 \\
\mathrm{hr} / \mathrm{yr}\end{array}$ \\
\hline
\end{tabular}





\section{SECIION I}

\section{WATER HEATER}

\section{TNLET WATTER TEMPERATURE}

CURRENT VALUE: $55^{\circ} \mathrm{F}$

PROPOSED VATUE: $58^{\circ} \mathrm{F}$

\section{HISIORTCAL BASTS FOR CURRENT VALUE}

Test methods were developed for water heaters in 1977 [1, 2] * in support of Public Law 94-163 which required the Federal Energy Administration [now the Department of Energy] to carry out energy conservation activities related to household appliance efficiency. These test methods were developed by the National Bureau of Standards with cooperation from the Gas Appliance Manufacturers Association and were based on the ANSI Standards 221.10.1 for Gas Water Heaters and C72.I for Electric Water Heaters and on earlier test procedures published in the Federal Register on August 14, 1975 (40 FR 158) for the Commerce Department Voluntary Labeling Program.

The test procedures of Reference [1] (Section 2.1.2.4) provide a rationale for selecting a National average inlet water temperature of $55^{\circ} \mathrm{F}$. The average water temperature is calculated as the mean of annual median temperatures for subdivisions of the United states and the water heater inlet water temperature for each of these subdivisions is considered to be equivalent to the local surface water temperature of streams, rivers, and lakes. This average surface temperature throughout the United States is approximately $55^{\circ} \mathrm{F}$.

\footnotetext{
* Numbers in brackets pertain to references listed at end of each section.
} 
A study of Household Appliance Usage Data [3] also cites an inlet water temperature of $55^{\circ} \mathrm{F}$ for water heaters. The report comments that this value has a marginal empirical basis, and in view of the importance of water heaters to the energy program, recommends independent field verification.

Reference [1] also states that it would be inappropriate to specify an inlet water temperature of $55^{\circ} \mathrm{F}$ for laboratory test purposes since this would require cooling of the tap water in the summer months when tap water temperature can be above $55^{\circ} \mathrm{F}$. Therefore, a $70^{\circ} \mathrm{F} \pm 2{ }^{\circ} \mathrm{F}$ feed-water temperature which can normally be achieved in laboratories throughout the year is specified in the test procedures. This increase of $15^{\circ} \mathrm{F}$ is also matched by a $15^{\circ} \mathrm{F}$ increase in outlet temperature from $145^{\circ} \mathrm{F}$ to $160^{\circ} \mathrm{F}$ (see SECTION II - WATER HEATERS - OUTLET WATER TEMPERATURE) to maintain a specified $\Delta T$ (outlet water temperature minus inlet water temperature). APPROACH FOR UPDATE

The current value of $55^{\circ} \mathrm{F}$ is based on the average for all regions of the United States of the median annual surface water temperature of the streams, rivers, and lakes in those regions. No consideration, however, is given to the specific location of the Nation's housing units. For example, if all housing units were located in the southern parts of the country, we might expect a higher average water heater inlet temperature than if all the housing units were located along the Canadian border. Therefore, in calculating the average inlet water temperature, the median annual water temperature of an area should be weighted by the number of water heaters in that area. In effect, the average water heater inlet temperature is not an unchanging geological quantity, as the average annual surface or ground water temperature might be, but rather changes with population shifts. Concurrent with the continuing population migration to 
the warmer regions of the United States $[5,6]$, the average water heater inlet temperature should also be increasing.

Accordingly, the approach taken was to estimate water heater inlet temperature on a housing population-weighted basis and average surface water temperatures for each State as described below. Temperatures were then weighted by the State's 1980 housing population to calculate a National average water inlet temperature. This was also done for the 1970 population to verify the upward inlet water temperature change from 1970 to 1980 in keeping with population shifts.

\section{RESULIS AND DISCUSSION}

In this study, the median annual surface-water temperatures in the conterminous United States were used [4]. These temperatures were determined by the U.S. Geological Survey and are reflected on a map showing isothermal bands of median annual temperature ranges for surface water (see Figure 1-1). The bands generally have a $5^{\circ} \mathrm{F}$ spread; however at the highest and lowest ranges, the bands represent surface water temperatures of $" 70^{\circ} \mathrm{F}$ or higher" and " $39^{\circ} \mathrm{F}$ or less," respectively.

Using the U.S. Geological Survey map, a single representative water heater inlet temperature was estimated for each State (see Table 1-1). Where a single isothermal band covers a State, the midpoint of the band was generally used. Where more than one band covers a State, an average inlet water temperature for the entire state was not assigned solely on the geographical distribution of the isothermal bands within the State, but was based on the housing population distribution. For example, if a State was covered by two isothermal bands, a uniform housing population would lead to selection of the boundry temperature of the two bands. If, however, the centers of population were generally located within one of the bands, a surface water temperature within that band was selected to represent the 
average inlet water temperature for that State.

The above method is subjective in that judgment was required to select a representative inlet water temperature for each State, especially for those States which lie in areas which have no fixed upper or lower limits to the isothermal bands (bands that are defined as $70^{\circ} \mathrm{F}$ or higher; or bands defined as $39{ }^{\circ} \mathrm{F}$ or less). Nevertheless, it is felt that a fair assessment has been made and that the selected temperatures shown in Table 1-1 would vary by a small amount even in those cases where there is room for other assessments of individual state inlet water temperatures. The overall results, however, should not be significantly altered as a result of these differences.

Also important to this study is the location of the Nation's housing population. This was determined by the use of 1980 census data [5]. The 1980 housing census divides housing by number of units per building: single-family units; 2-9 units per building; and more than 9 units per building. (The number of single family and 2 to 9 units per building, by State, are also tabulated in Table 1-1.) Since this study is focused on small residential water heaters it was assumed that all single-family units would have one water heater each and that buildings having more than 9 units would not have any residential size water heaters. For buildings having 2-9 units, calculations were made assuming that only one-eighth of the units had individual water heaters; two-eights of the units had individual water heaters, etc.; and finally, that all of these units had individual water heaters. The computed fractions were added to the singlefamily units to arrive at State residential water heater populations for each increment. 
The above information permitted the calculation of a weighted National average inlet water temperature for small residential water heaters by multiplying the number of water heaters per State by the average water surface temperature, adding the products, and dividing by the total estimated number of water heaters. This information is presented in Table 1-1 for single-family units and for 2-9 units incremented as described above. As can be seen, the housing population-weighted average water inlet temperature is $58.5^{\circ} \mathrm{F}$ for single-family houses and varies from $58.2^{\circ} \mathrm{F}$ to $58.4^{\circ} \mathrm{F}$ if buildings having $2-9$ dwelling units are included in the estimate. This shows that neglecting multi-unit buildings has little effect on the average inlet water temperature.

To see whether the housing population-weighted average inlet water temperature increased from 1970 to 1980 as might be expected by population movement to warmer climates, the same calculations were also performed for singlefamily houses using 1970 census data [6]. The 1970 census divides the population into only 2 categories: single-family and more than one unit per dwelling. Only single-family data were used and are shown in Table 1-1 along with the calculated average water inlet temperature of $58.2^{\circ} \mathrm{F}$ for 1970 . The increase in housing population-weighted average inlet water temperature for single-family units from $58.2^{\circ} \mathrm{F}$ for 1970 to $58.5^{\circ} \mathrm{F}$ for 1980 is in the expected direction. Because any errors made in estimating temperatures, especially those arising from considering only singlefamily houses, were probably similar for the two years studied, this change in temperature is probably fairly accurate. RECOMMENDATIONS

Lacking field data and in view of the information presented above, a National inlet water temperature for residential water heaters of $58^{\circ} \mathrm{F}$ is 
recommended. This factor should be reviewed if significant field data of actual inlet water temperatures are collected or other information becomes available that has the potential to provide further refinement.

\section{REFERENCES}

[1] Test Procedure Review-Water Heaters; Recommendations conceming test procedures to be proposed for use under Public Law 94-163 for Federal Energy Administration Appliance Efficiency Program by the National Bureau of Standards, Center for Consumer Product Technology, March 10, 1976 Revised April 21, 1977.

[2] Federal Register; Federal Energy Administration; Energy Conservation Program for Appliances; Test Procedures for Water Heaters; Tuesday, October 4, 1977; Part III.

[3] Household Appliance Usage Data; NBSIR 80-1994; Alan D. Davies, et. al.; dated February 1980 (Final Report issued March 1980).

[4] J. F. Blakey; "Temperature of Surface Waters in the Conterminous United States;" U.S. Geological Survey Hydrologic Investigations Atlas HA-235; Washington, D.C., 1966.

[5] U.S. Department of Commerce,"1980 Census of Housing Volume 1 , Characteristics of Housing Units; Chapter A, General Housing Characteristics; Part 1, United States Sumary."

[6] U.S. Department of Commerce, "1970 U.S. Census of Housing; Volume 1 , Housing Characteristics for State, Cities, and Countries; Part l, United States Survey." 


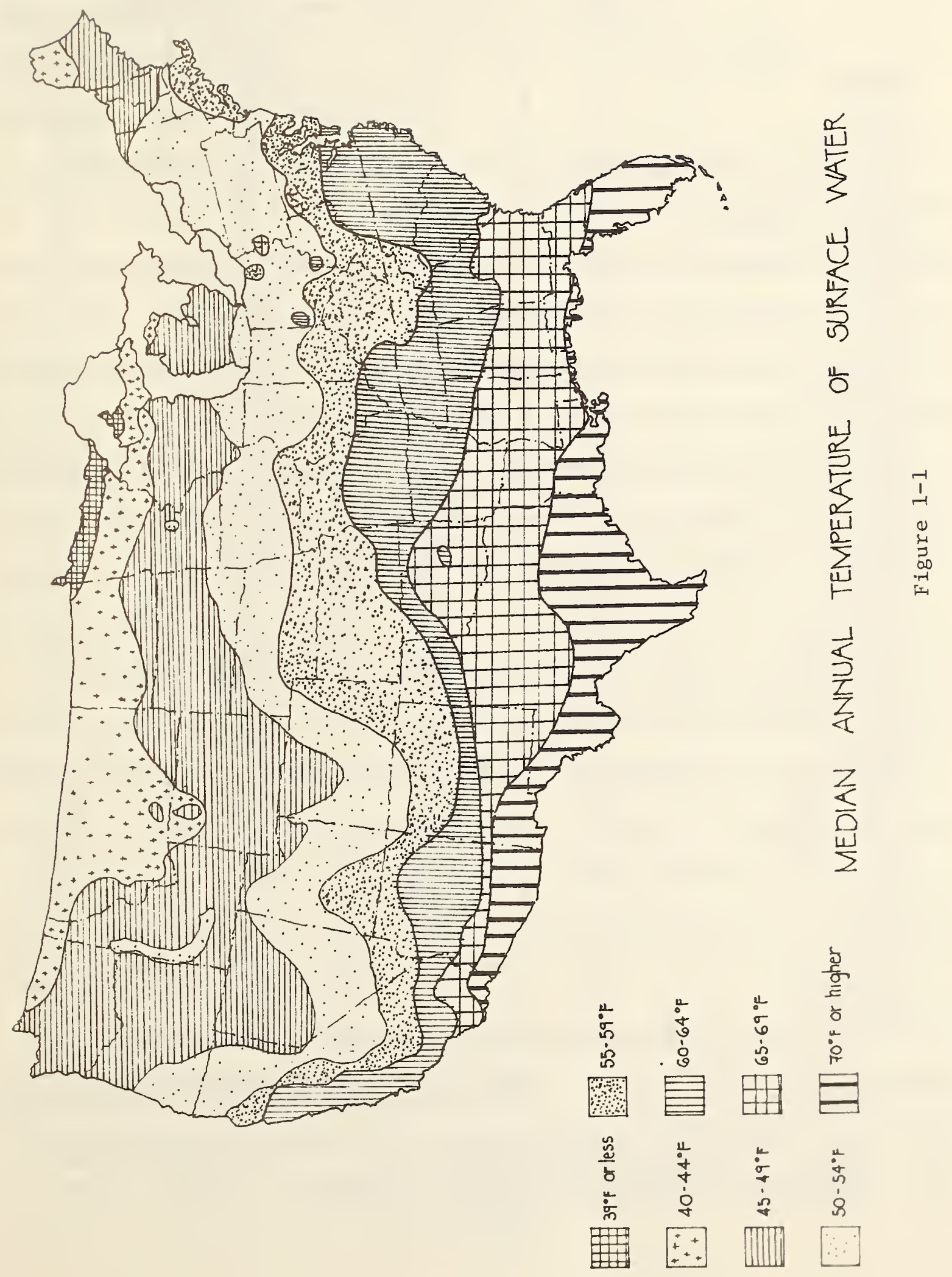


TABLE $1-1$

HOUSING POPULATION-WEIGHTED AVERAGE SURFACE WATER TEMPERATURE

\begin{tabular}{|c|c|c|c|c|}
\hline \multirow[b]{3}{*}{ STATE } & \multirow{3}{*}{$\begin{array}{l}\text { ASSUMED } \\
\text { AVERAGE } \\
\text { INLET } \\
\text { WATER } \\
\text { TEMPERATURE } \\
{ }^{\circ} \mathrm{F}\end{array}$} & \multicolumn{3}{|c|}{ HOUSING POPULATION (IN THOUSANDS) } \\
\hline & & \multirow{2}{*}{$\begin{array}{l}1970 \text { CENSUS } \\
\text { SINGLE FAMILY } \\
\text { UNITS }\end{array}$} & \multicolumn{2}{|c|}{1980 CENSUS } \\
\hline & & & $\begin{array}{l}\text { SINGLE FAMILY } \\
\text { UNITS }\end{array}$ & $\begin{array}{l}\text { 2-9 UNITS PER } \\
\text { BUILDING }\end{array}$ \\
\hline $\begin{array}{l}\text { Alabama } \\
\text { Arizona } \\
\text { Arkansas } \\
\text { California } \\
\text { Colorado } \\
\end{array}$ & $\begin{array}{l}67 \\
70 \\
65 \\
63 \\
52 \\
\end{array}$ & $\begin{array}{r}929 \\
426 \\
577 \\
4,696 \\
534 \\
\end{array}$ & $\begin{array}{r}1,168 \\
745 \\
725 \\
6,440 \\
835 \\
\end{array}$ & $\begin{array}{r}111 \\
87 \\
62 \\
1,148 \\
107 \\
\end{array}$ \\
\hline Connecticut & 56 & 572 & 794 & 241 \\
\hline Delaware & 55 & 133 & 170 & 21 \\
\hline District of Columbia & 57 & 102 & 127 & 58 \\
\hline Florida & 73 & 1,740 & 2,798 & 429 \\
\hline Georgia & 64 & 1,107 & 1,525 & 205 \\
\hline Idaho & 47 & 192 & 272 & 33 \\
\hline Illinois & 52 & 2,197 & 2,699 & 1,025 \\
\hline Indiana & 54 & 1,341 & 1,655 & 214 \\
\hline Iowa & 52 & 783 & 902 & 117 \\
\hline Kansas & 57 & 645 & 775 & 81 \\
\hline Kentucky & 57 & 850 & 1,045 & 144 \\
\hline Louisiana & 72 & 897 & 1,195 & 149 \\
\hline Maine & 47 & 230 & 295 & 83 \\
\hline Maryland & 57 & 852 & 1,145 & 202 \\
\hline Massachusetts & 55 & 925 & 1,257 & 636 \\
\hline Michigan & 46 & 2,162 & 2,721 & 368 \\
\hline Minnesota & 47 & 895 & 1,128 & 163 \\
\hline Mississippi & 67 & 598 & 732 & 65 \\
\hline Missouri & 62 & 1,228 & 1,518 & 243 \\
\hline Montana & 42 & 180 & 222 & 40 \\
\hline Nebraska & 55 & 408 & 493 & 60 \\
\hline Nevada & 50 & 105 & 203 & 39 \\
\hline New Hampshire & 47 & 158 & 235 & 71 \\
\hline New Jersey & 55 & 1,334 & 1,710 & 638 \\
\hline New Mexico & 58 & 263 & 347 & 53 \\
\hline New York & 55 & 2,487 & 3,096 & 1,758 \\
\hline North Carolina & 62 & 1,341 & 1,761 & 181 \\
\hline North Dakota & 42 & 149 & 174 & 38 \\
\hline Ohio _ & 55 & 2,482 & 3,119 & 520 \\
\hline Oklahōma & 67 & 798 & 1,010 & 98 \\
\hline Oregon & 50 & 570 & 812 & 85 \\
\hline Pennsylvania & 52 & 2,821 & 3,415 & 658 \\
\hline Rhode Island & 57 & 159 & 221 & 107 \\
\hline South Carolina & 64 & 669 & 883 & 89 \\
\hline South Dakota & 47 & 178 & 200 & 32 \\
\hline Tennessee & 60 & 1,041 & 1,373 & 163 \\
\hline Texas & 72 & 3,069 & 4,143 & 450 \\
\hline Utah & 52 & 234 & 372 & 54 \\
\hline Vermont & 47 & 99 & 135 & 41 \\
\hline Virginia & 60 & 1,112 & 1,554 & 206 \\
\hline Washington & 47 & 913 & 1,225 & 154 \\
\hline West Virginia & 55 & 491 & 577 & 66 \\
\hline Wisconsin & 47 & 999 & 1,321 & 262 \\
\hline Wyoming & 47 & 86 & 118 & 24 \\
\hline
\end{tabular}

Population-weighted

National average inlet water temperature $\left({ }^{\circ} \mathrm{F}\right)$.

\begin{tabular}{l|l|l|l}
58.2 & 58.5 & $58.2-58.4 *$
\end{tabular}

* Range is based on the calculation that one-eight of these units had individual water heater; two-eights had individual water heaters, etc.. The individual calculations are as follows: $1 / 8-58.4^{\circ} \mathrm{F} ; 2 / 8-58.4^{\circ} \mathrm{F} ; 3 / 8-58.4^{\circ} \mathrm{F} ; 4 / 8-58.3^{\circ} \mathrm{F}$; $5 / 8-58.3^{\circ} \mathrm{F} ; 6 / 8-58.3^{\circ} \mathrm{F} ; 7 / 8-58.3^{\circ} \mathrm{F} ; 8 / 8-58.2^{\circ} \mathrm{F}$. 
SECIION II

WATYER GFETMER

\section{OUTHET WATER TEMPERATURE}

\section{CURRENI VALUE: $145^{\circ} \mathrm{F}$}

\section{PROPOSED VALUE: $135 \%$}

\section{HTSIORTCAL BASIS FOR CURRENT VALUE}

Test methods were developed for water heaters in 1977 [1] in support of Public Law 94-163 which required the Federal Energy Administration to carry out energy conservation activities related to household appliance efficiency. These test methods were developed by the National Bureau of Standards with cooperation from the Gas Appliance Manufacturers Association and were based on ANSI Standards 221.10.1 for Gas Water Heaters and C72.1 for Electric Water Heaters using the appropriate sections from each of these standards and on earlier test procedures published in the Federal Register on August 14, 1975 (40 FR 158) for the Commerce Department Voluntary Labeling Program.

The test procedures of Reference [1] (Section 2.1.2.4) provide a rationale for selecting a National average outlet temperature of $145^{\circ} \mathrm{F}$. The reason given is that water heater thermostats are factory set to achieve a tank water temperature of $145^{\circ} \mathrm{F}$. Reference [1] (Section 3.2.1) further states that the setting is assumed to be $145^{\circ} \mathrm{F}$ because gas water heater thermostats are normally set for $140^{\circ} \mathrm{F}$ and electric water heater thermostats are set for $150^{\circ} \mathrm{F}$.

A study made on Household Appliance Usage Data [2] also cites an outlet water temperature of $145^{\circ} \mathrm{F}$ for water heaters. The report comments that the empirical basis for this value is very marginal and in view of the importance of water heaters to the energy program, independent field verification of this factor is recommended. 
It should be noted that Reference [1] specifies a thermostat setting of $160^{\circ} \mathrm{F}$ when conducting water heater test procedures rather than the National average outlet temperature of $145^{\circ} \mathrm{F}$. This setting was required to maintain a specified $\Delta \mathrm{T}$ (outlet water temperature minus inlet water temperature) and resulted from raising the inlet water temperature $15^{\circ} \mathrm{F}$ (from $55^{\circ} \mathrm{F}$ to $70^{\circ} \mathrm{F}\left[+2^{\circ} \mathrm{F}\right]$ ) during testing so that the tap water used in the test procedures need not be cooled (see SECTION I - WATER HEATERS - INLET WATER TEMPERATURE) 。

APPROACH EOR UPDATE

The current National average for the outlet temperature for water heaters is derived from thermostat settings of gas and electric water heaters and were based on practices that were used during the early and middle 1970's. In conducting this study, it was concluded that this approach was reasonable and that the data should be updated to reflect current practices. Towards this end, manufacturers of gas-fired and electrical resistance water heater control thermostats were contacted as well as water heater manufacturers and trade associations to learn the temperatures at which units are set at the factory and/or by installers. In addition, data regarding the number of gas and electric water heaters manufactured was gathered to provide weighting factors in determining a single overall value for outlet temperature. Finally, data collected during field studies of gas and electric water heaters are included. RESULTS AND DISCUSSION

To determine the settings of electric thermostats for residential water heaters, representatives of two major manufacturers of water heater thermostats $[3,4]$ and two major manufacturers of water heaters $[5,6]$ were contacted. According to these representatives, currently-produced electric water heaters generally have a temperature range setting from $110^{\circ} \mathrm{F}$ to 
$170^{\circ} \mathrm{F}$; with index markings every ten degrees $\mathrm{F}$; and a screw-type adjustment which allows the temperature to be infinitely set between $110^{\circ} \mathrm{F}$ and $170^{\circ} \mathrm{F}$ (see Figure 2-1) [7]. In addition, each contacted representative stated that electric water heaters are shipped from the factory at a setting of $140^{\circ} \mathrm{F}$ as required by the April 18, 1983 Standard - "Household Electric Storage Tank Water Heaters - UL 174."

Specifically, the provisions of UL 174 state:

21.1 A temperature-regulating thermostat shall have no marked dial setting more than $77^{\circ} \mathrm{C}\left(170^{\circ} \mathrm{F}\right)$ and shall be provided with a stop to prevent its adjustment to a higher temperature setting.

21.3 A temperature-regulating thermostat or control shall be set before leaving the factory to a control position corresponding to a $60^{\circ} \mathrm{C}\left(140^{\circ} \mathrm{F}\right)$ setting. This setting may be approximate, as in the case of a marking that reads "Low-Medium High" or the equivalent, instead of directly in degrees $\mathrm{C}$ or $\mathrm{F}$.

Because the thermostat setting could be changed by the installer or occupant, each contacted representative was asked about the likelihood of such a change. It was the consensus that the installer would generally have no motivation to change the setting. Also, most homeowners are not familiar enough with the existance or location of the electric water heater thermostats to make a change and also would generally keep away from manipulating concealed line voltage electrical controls since most residential electric water heaters contain two thermostats which can be reached only after unscrewing a metal cover plate and pushing aside the water tank insulation which covers the thermostat. It was further postulated that those individuals who would be likely to perform such an operation would be those persons who are generally energy conscious and who would be inclined (and knowledgeable) to make the positive effort to lower 
the thermostat from the $140^{\circ} \mathrm{F}$ setting. In addition to the above, no field data were found which actually describe the thermostat settings of recently installed electric water heaters. Therefore, a National average thermostat setting for recently installed electric water heaters of $140^{\circ} \mathrm{F}$ seems reasonable.

For gas water heaters, information was also obtained from two major manufacturers of water heater thermostats [3, 4] and two major manufacturers of water heaters [5, 6] as well as from the American Gas Association [8]. A sumnary of the responses indicates that there is no standard, per se, on the significance of thermostat knob markings such as "Hot", "Energy Savings", "Low", etc. A review of ANSI 721.23 - 1980 - Gas Appliance Thermostats [9] reveals that the only reference to temperature dial marking for water heaters recommends a minimum marking of $100^{\circ} \mathrm{F}$ and a maximum marking of $180^{\circ} \mathrm{F}$ with a calibration reference point of $140^{\circ} \mathrm{F}$. However, the individuals contacted indicated that on most thermostats the following dial settings and corresponding temperatures are generally appliable:

$\begin{array}{ll}\text { HOT } & 160^{\circ} \mathrm{F} \\ \text { WARM } & 1200^{\circ} \\ \text { VACATION } & 110-115^{\circ} \mathrm{F}\end{array}$

In addition, a marking of "energy savings" would generally correspond to a setting of $130^{\circ} \mathrm{F}$ (see Figure $2.1(\mathrm{a}),(\mathrm{b}),(\mathrm{c}),(\mathrm{d})$ ) [10] and that gas water heater thermostats are set at their lowest setting when the gas water heater leaves the manufacturer and reset for $130^{\circ} \mathrm{F}$ during installation. As a reference, American National Standard ANSI Z21.10.1b - 1983 was cited [11]. Specifically, the provisions state:

\subsection{INSTRUCTIONS}

1.29.1 Each water heater shall be accompanied by clear, concise 
printed instructions and diagrams,....

e. Thermostat information to the effect that:

1. The thermostat is adjusted to its lowest temperature position when shipped from the factory.

2. The detent or marking, as applicable, on the thermostat is the preferred starting point for setting the temperature control (see 1.30.10).

3. Procedures for adjusting the thermostat for energy efficient operation at the minimum water temperature setting consistent with the consumers needs.

1.30.10 Each adjustable thermostat shall have a detent or legible marking on Class III A material consistent with a water temperature of approximately $130^{\circ} \mathrm{F}\left(54.5^{\circ} \mathrm{C}\right)$.

The potential for thermostat setting change is greater for gas water heaters than for electric water heaters since gas water heater thermostats are more accessible. Older people might lower the setting to avoid scalding as might energy concious individuals. On the other hand, people in large households might increase the setting to accommodate a higher demand for hot water. No field data were found which actually describe the thermostat settings of recently installed gas water heaters, however, in view of the above, a National average thermostat setting for recently installed gas water heaters of $130^{\circ} \mathrm{F}$ seens reasonable.

With regard to the distribution of gas and electric water heaters information received from the Gas Appliance Manufacturers Association [12] indicates an almost even shipment distribution between gas and electric water heaters (see Table 2-1). With this equal distribution of units and an average setting for electric water heaters of $140^{\circ} \mathrm{F}$ and $130^{\circ} \mathrm{F}$ for gas water heaters, a single National averge outlet water temperature for 
recently installed gas and electric water heaters of $135^{\circ} \mathrm{F}$ seems reasonable.

Because many older water heaters are still in service, outlet temperatures of older water heaters were also of interest and in a field study conducted in 1976 - 1977 data were collected for 5 electric and 5 gas-fired normally operating water heaters in new townhouses in Twin Rivers, New Jersey [13]. In this study, outlet temperatures ranged from $145.5^{\circ} \mathrm{F}$ to $163.2^{\circ} \mathrm{F}$; with an average outlet water temperature of $158.2^{\circ} \mathrm{F}$ for gas-fired water heaters and $148.5^{\circ} \mathrm{F}$ for electric water heaters. Only one water heater had an outlet temperature below $145^{\circ} \mathrm{F}$. This sample may not have been representative of the National average at the time since the sample was small, at a single location, and conducted in a test environment. However, water heaters were generally set at a higher outlet temperature during that time frame and the Twin Rivers study seems to confirm this. Since the average lifetime of a water heater is 13 years [14], it could be expected that the National average water heater outlet water temperature settings over a thirteen year period would tend to approach those of current production due to the effects of energy conservation activities, the adoption of new standards, the replacement of older water heaters, and the installation of water heaters in new housing. CONCLUSIONS AND RECOMMENDATIONS

It appears that the current value for a National averge outlet water temperature of $145^{\circ} \mathrm{F}$ for water heaters is probably quite reasonable for the 1984 time frame. However, as the inventory of water heaters is turned over during the 13 year average lifetime, a value approaching $135^{\circ} \mathrm{F}$ is more appropriate. A suggested table of values, by year, is shown in Table 2-2. The selection of an outlet water temperature would depend on its intended use. 
If used for test procedure development, the $135^{\circ} \mathrm{F}$ outlet temperature is recommended to reflect a single National average outlet water temperature for currently produced gas and electric water heaters although this value might be modified, along with the inlet water temperature, in order to facilitate testing. If used for energy savings evaluations or economic studies and a more time dependent value is needed to reflect the removal of older water heaters from service, the appropriate temperatures should be selected from the time/temperature relationship shown in Table 22. If the year in question goes beyond 1990, an update in inlet water temperature should also be considered to reflect the effects of further housing population shifts (see SECTION I - WATER HEATERS - INLET WATER TEMPERATURE) •

\section{REFERENCES}

[1] Test Procedure Review-Water Heaters; Recommendations concerning test procedures to be proposed for use under Public Law 94-163 for Federal Energy Administration Appliance Efficiency Program by the National Bureau of Standards, Center for Consumer Product Technology March 10, 1976, Revised April 21, 1977.

[2] Household Appliance Usage Data; NBSIR 80-1994; Alan D. Davies, et. al.; dated February 1980 (Final Report Issued March 1980).

[3] Robert Shaw, Grayson Division, Long Beach, CA.

[4] White Rogers, St. Louis, MO.

[5] Reliance, Ashland City, Tennessee.

[6] Rheem, Chicago, IL.

[7] From a sample of residential electric water heaters used for a variety of water heater projects at the National Bureau of Standards.

[8] Letter from S. L. Blackman; dated February 27, 1984; American Gas Association Laboratories; Cleveland, Ohio. 
[9] ANSI 721.23-1980; American National Standards for Gas Appliance Thermostats; Approved December 31, 1980; Secretariat American Gas Association; Arlington, VA。

[10] From a sample of residential gas water heaters used for a variety of water heater projects at the National Bureau of Standards and from gas water heaters currently being sold by Sears.

[11] ANSI 221.10.1b-1983; Addenda to American National Standard 22.10.11981, 221.10.1a-1983; for Gas Water Heaters; Volume 1 - Automatic Storage Water Heaters With Inputs of 75,000 Btu Per Hour or Less; Approved February 15, 1983; Secretariat-American Gas Association; Arlington, VA,

[12] Statistical Highlights; Ten Year Summary, 1973-1982, Gas Appliance Manufacturers Association; Arlington, VA.

[13] Ro A. Grot; Field Performance of Gas and Electric Water Heaters; Proceedings of the Conference on Major Home Appliance Technology for Energy Conservation; February 27 - March 1, 1978; Purdue University, West Lafayette, Indiana.

[14] U.S. Department of Energy; Consumer Product Efficiency Standards Economic Analysis Document; Report Number DOE/CE 0029 1982; Washington, D.C. 
Figure 2-1

WATER HEATER THERMOSTAT DIALS (TypICOI)

ELECTRIC

$$
=8
$$

GAS

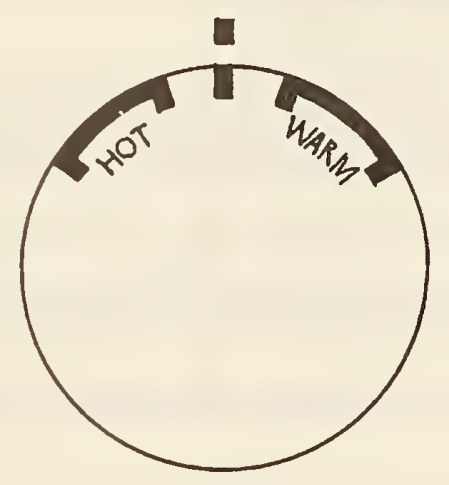

(A)

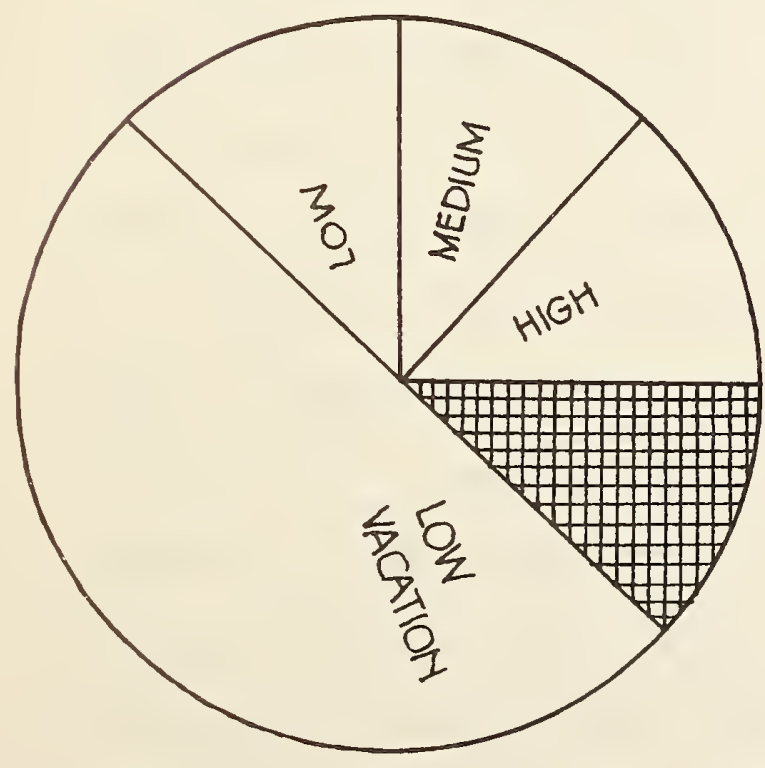

(c)

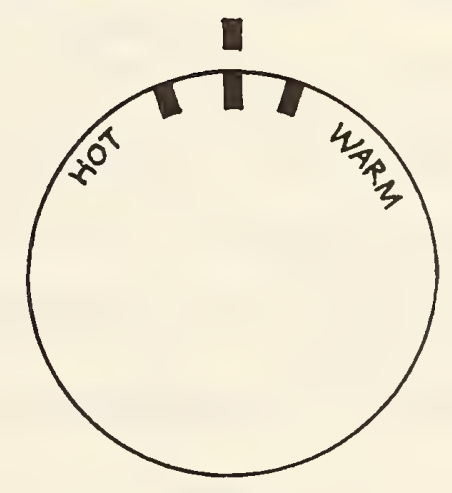

(B)

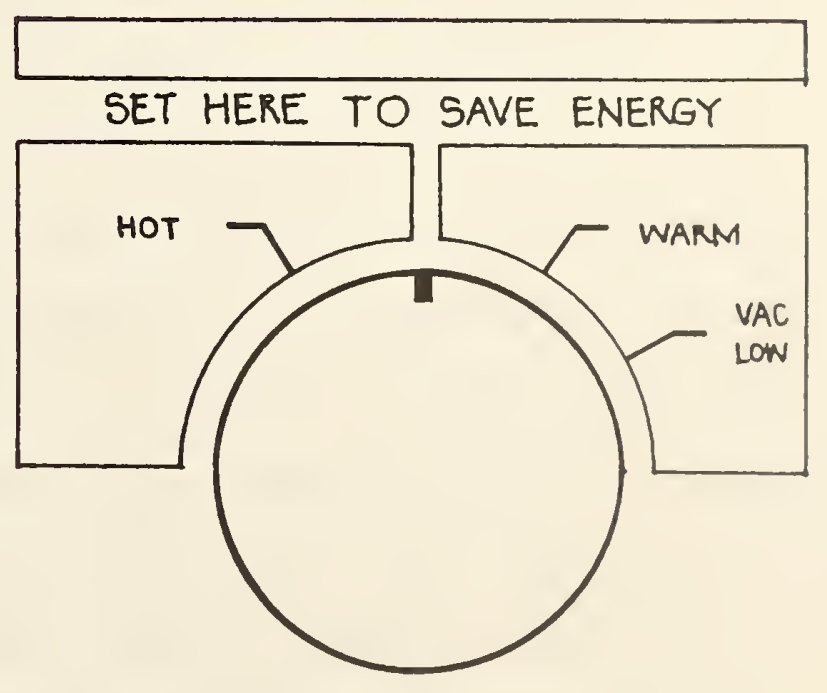

(D) 
Table 2-1

SHIPMENTS OF RESTDENTLAC, WRTER HEATERS

(in thousands)

\begin{tabular}{|l|r|r|r|r|c|}
\cline { 2 - 6 } \multicolumn{1}{c|}{} & 1979 & 1980 & 1981 & 1982 & 1983 \\
\hline Water Heaters, Gas & 2,887 & 2,818 & 2,785 & 3,040 & 3,172 \\
\hline Water Heaters, Electric & 2,661 & 2,451 & 2,463 & 2,716 & 3,131 \\
\hline
\end{tabular}

Table 2-2

AVERAGE OUTLET WATER TEMPERATURE BY YEAR

\begin{tabular}{|l|c|c|c|c|c|c|c|c|c|c|c|c|c|c|}
\hline Year & 84 & 85 & 86 & 87 & 88 & 89 & 90 & 91 & 92 & 93 & 94 & 95 & 96 & 97 \\
\hline $\begin{array}{l}\text { National Average } \\
\text { Outlet Water } \\
\text { Temperature for } \\
\text { Water Heaters } \\
\text { OF }\end{array}$ & 145 & 144 & 143 & 143 & 142 & 141 & 140 & 140 & 139 & 138 & 137 & 137 & 136 & 135 \\
\hline
\end{tabular}


SECTION III

WATER HEATER

AMBIENI ATR TEMPERATURE

CURRENT VALUE: $55{ }^{\circ} \mathrm{F}$

PROPOSED VALUE: $65{ }^{\circ} \mathrm{F}$

\section{HISTORICAL BASIS FOR CURRENT VALUE:}

Test methods were developed for water heaters in 1977 [1] in support of Public Law 94-163 which required the Federal Energy Administration to carry out energy conservation activities related to household appliance efficiency. These test methods were developed by the National Bureau of Standards with cooperation from the Gas Appliance Manufacturers Association and were based on ANSI Standards 721.10.1 for Gas Water Heaters and C72.1 for Electric Water Heaters using the appropriate sections from each of these standards and on earlier test procedures published in the Federal Register on August 14, 1975 (40 FR 158) for the Commerce Department Voluntary Labeling Program.

The Federal Register documenting proposed rules for the Energy Conservation Program for Consumer Products [2] includes the determination of the current value of $55^{\circ} \mathrm{F}$ for a national average room temperature. It states "... the national average room ambient air temperature specification of $55^{\circ} \mathrm{F}$ was derived by calculation using field data on actual gas and electric storage water heater energy consumption in the residential sector obtained from a survey of 50 gas and 50 electric utility companies conducted by NBS in July 1974." Thirty-eight companies responded to this survey, eighteen of them supplied metered data. The data obtained were normalized to a $90^{\circ} \mathrm{F}$ water temperature rise and a family size of four persons. Two of the companies responding supplied data on both water usage 
and energy usage. NBS used the data supplied by these two companies to compute an average energy efficiency factor (combination of recovery efficiency and standby losses) for gas and electric storage water heaters. These energy efficiency factors were then applied to the energy use data supplied by the other companies to derive average hot water usage of households and associated average room ambient air temperature. Following this approach, NBS determined the average hot water usage of households to be 450 gallons per week, or 64.3 gallons per day and the average room ambient air temperature to be $55^{\circ} \mathrm{F}$ for the purposes of DOE's test procedures for water heaters. DOE acknowledged at the time that this average ambient room temperature specification may or may not simulate actual ambient temperature conditions where water heaters are installed; however, the use of this specification coupled with the daily hot water usage specification of 64.3 gallons per day resulted in calculated values of energy consumption that agree reasonably well with actual energy consumption obtained from field data.

In addition, a study of Household Appliance Usage Data [3] addressing the basis for room ambient temperature, states "no information was provided on whether the water heaters were usually located outside the house, in unheated cellars, or inside the heated or air conditioned volumes of housing units." The study concludes ".... independent field verification of each of these usage factors is recommended. It is suspected that a value for $\mathrm{T}_{\mathrm{r}}$ [room temperature] nearer to $70^{\circ} \mathrm{F}$ than to $55^{\circ} \mathrm{F}$ will be found, for example."

Finally, reference [2] also states that the existing test procedures for water heaters require the ambient air temperature to be maintained at a temperature between $65^{\circ} \mathrm{F}$ and $85^{\circ} \mathrm{F}$ (and not vary more than $\pm 7^{\circ} \mathrm{F}$ throughout the test). It was for the convenience of testing that this temperature was 
elevated $10^{\circ} \mathrm{F}$ to $30^{\circ} \mathrm{F}$ (from $55^{\circ} \mathrm{F}$.

\section{APPROACH EOR UPDATE}

The ambient water heater temperature is, of course, based on the location of the water heater which in turn is a function of the house configuration, climate, and in same cases fuel type. House configuration determines the possible location of the water heater in that houses built with basements would normally have their water heaters located in those basements. Houses built solely with crawl spaces, however, would have their water heaters placed elsewhere since most crawl spaces usually are too low to accomodate water heaters. In addition, crawl spaces generally provide an unreasonable access for setting, servicing, maintaining or replacing water heaters. In houses built on grade (concrete slab), water heaters are generally placed within the conditioned square footage such as closets or laundry rooms. Water heaters may also be placed in garages or, in milder climates, in spaces outside of the heated or air conditioned volumes of the house.

Fuel type also affects the placement of water heaters. If a water heater is fueled by gas, the fumace generally would also be gas fueled and the water heater placed near the furnace to avoid running extra lengths of gas pipe. This placement of water heaters in proximity to furnaces would generally prevail for all types of installation; basement, closet, garage, etc. Electric water heaters on the other hand, may be located, in principle, anywhere in or near the houses. From a practical point, however, if a basement exists, the electric water heater would also be placed near the furnace to keep all utility type equipment together to allow for more flexible use of the remaining basement space.

The approach for update of this factor is based on a search for data involving the most likely location for the water heater and the ambient 
temperature at that location. Very little data in this regard were identified, however, some census data did provide an insight into determining a representative value for this factor.

\section{RESUTIS AND DISCUSSION}

In addressing the detemination of a water heater ambient temperature, Census Data were reviewed to detemine the national population for housing with and without basements [4]. A summary of Housing Basement Data is presented for 1977 and 1970 in Table 3-1. These data indicate that for all year round housing units, 47.48 of the total U.S. Housing in 1977 had basements - a reduction from 54.38 in 1970 . This trend to fewer basements is not surprising as the cost of housing increases and affordability decreases. The greatest number of basements in 1977 were in the colder climates with $85.5 \%$ of the housing in the North East having basements and 70.48 for the North Central region. Housing in the South and West having basements were 18.28 and 22.08 respectively. These data were for all types of residential units from apartment buildings to single family detached houses.

Another source of data which concentrates solely on single family units was derived from the Energy Information Administration of the Department of Energy [5] and is shown in Table 3-2. For single family units the data combine basements and crawl spaces and do not present information separating the two. Again, the number of basement/crawl space single family units are greatest in the North East and North Central regions ( $87.5 \%$ and 90.88 respectively) and lowest in the South and west $(69.58$ and 65.18$)$.

Unfortunately, no definitive numerical conclusions can be drawn from the above data. However, one can observe that there are a large number of basements in the colder climates of the North East and North Central parts 
of the country with many of the basements directly heated. Residences in the south and West, with their warmer climates, have fewer basements with a smaller percentage directly heated. If it can be assumed that (I) the water heater will be generally located in the basement when a basement is available and (2) the number and distribution of residential basements are geographically wide ranging as described above, than it is hard to imagine the surrounding ambient temperature of the water heater being as low as $55^{\circ} \mathrm{F}$, the current value. In the wintertime, directly heated basements might range in the order of $65^{\circ} \mathrm{F}$ to $70^{\circ} \mathrm{F}$ while unheated basements might range in the $60^{\circ} \mathrm{F}$ to $65^{\circ} \mathrm{F}$ region due to heat being radiated from a nearby fumace or boiler. Also in the summertime, the basement temperature would generally be higher than $55^{\circ} \mathrm{F}$ when the outside temperature fluctuates between $70^{\circ} \mathrm{F}$ and $90^{\circ} \mathrm{F}$, as might be expected.

Regarding the ambient temperature for water heaters not located in basements, a strong argument can be made for assuming that the water heater ambient temperature would generally be the same as the prevailing ambient temperature in the residence. To determine this temperature, data showing the percentage of U.S. Households by inside temperatures were identified. These data, shown in Table 3-3, were developed by the Energy Information Administration of the Department of Energy [5] and show (1) Daytime Temperature When Someone Is At Home; (2) Daytime Temperature When No one Is At Home; and, (3) Nightime (Sleeping Hours) Temperatures. The information is for winter indoor temperatures and is classified by heating degree days and residence square footage. An inspection of the data reveals that the percentage of indoor winter temperatures less than $63^{\circ} \mathrm{F}$ is relatively small. In the summertime, of course, the indoor ambient temperature would be much higher, even with air conditioning. 


\section{RECOMMENDATTONS}

It would be difficult to justify the current value of $55^{\circ} \mathrm{F}$ as a National average ambient water heater temperature based on a critical review of the data presented above. Although impossible to quantify with the data available, a value of $65^{\circ} \mathrm{F}$ to $70^{\circ} \mathrm{F}$ seems more supportable. In view of the above, it is recommended that a value of $65^{\circ} \mathrm{F}$ be used until a better approach can be developed or actual fleld data collected.

\section{REFERENCES}

[1] Test Procedure Review - Water Heaters; Recommendations conceming test procedures to be proposed for use under Public Law 94-163 for Federal Energy Administration Appliance Efficiency Program by the National Bureau of Standards, Center for Consumer Product Technology; March 10, 1976, Revised April 21, 1977.

[2] Federal Register; Department of Energy; Part II; Office of Conservation and Renewable Energy; 10 CFR Part 430, Energy Conservation Program for Consumer Products; Test Procedures for Water Heaters; Public Heating; Proposed Rule; Wednesday, February 8, 1984.

[3] Household Appliance Usage Data; NBSIR 80-1994; Alan D. Davies, et. al.; dated February 1980 (Final Report issued March 1980).

[4] Annual Housing Survey: 1977; General Housing Characteristics; Part A - United States and Regions; U.S. Department of Commerce; Bureau of the Census/U.S. Department of Housing and Urban Development; Office of Policy Development of Research.

[5] Residential Energy Consumption Survey: Housing Characteristics 1982; DOE/EIA-0314(82); Published August 1984; Energy Information Administration, Washington, DC 20585. 
TABLE 3-1

HOUSING BASEMENT DATA

(all year round housing units)

1977

\begin{tabular}{|c|c|c|c|c|c|c|}
\hline & & $\begin{array}{l}\text { Total } \\
\text { US }\end{array}$ & $\begin{array}{l}\text { North } \\
\text { East }\end{array}$ & $\begin{array}{c}\text { North } \\
\text { Central }\end{array}$ & South & West \\
\hline \multirow{2}{*}{$\begin{array}{l}\text { Housing } \\
\text { With } \\
\text { Basement }\end{array}$} & $\begin{array}{c}\text { Number } \\
\text { (Thousand) }\end{array}$ & 38253 & 15141 & 14920 & 4797 & 3395 \\
\hline & $\%$ & 47.4 & 85.5 & 70.4 & 18.2 & 22.0 \\
\hline \multirow{2}{*}{$\begin{array}{l}\text { Housing } \\
\text { Without } \\
\text { Basement }\end{array}$} & $\begin{array}{c}\text { Number } \\
\text { (Thousand) }\end{array}$ & 42463 & 2566 & 6261 & 21625 & 12011 \\
\hline & $\%$ & 52.6 & 14.5 & 29.6 & 81.8 & 78.0 \\
\hline
\end{tabular}

1970

\begin{tabular}{|l|c|c|c|c|c|c|}
\hline \multicolumn{2}{|c|}{} & $\begin{array}{c}\text { Total } \\
\text { US }\end{array}$ & $\begin{array}{c}\text { North } \\
\text { East }\end{array}$ & $\begin{array}{c}\text { North } \\
\text { Central }\end{array}$ & South & West \\
\hline $\begin{array}{l}\text { Housing } \\
\text { With } \\
\text { Basement }\end{array}$ & $\begin{array}{c}\text { Number } \\
\text { (Thousand) }\end{array}$ & 34467 & 13843 & 13452 & 4180 & 2992 \\
\cline { 2 - 6 } & $\%$ & 54.3 & 89.4 & 76.7 & 21.7 & 26.8 \\
\hline $\begin{array}{l}\text { Housing } \\
\text { Without } \\
\text { Basement }\end{array}$ & $\begin{array}{c}\text { Number } \\
\text { (Thousand) }\end{array}$ & 28978 & 1640 & 4084 & 15077 & 8177 \\
\cline { 2 - 7 } & $\%$ & 45.7 & 10.6 & 23.3 & 78.3 & 73.2 \\
\hline
\end{tabular}

Source:

Annual Housing Survey: 1977

General Housing Characteristics 
TABLE 3-2

SINGLE-FAMILY BASEMENT DATA

(SINGLE-FAMILY UNITS - 1982)

\begin{tabular}{|c|c|c|c|c|c|c|}
\hline & & $\begin{array}{l}\text { TOTAL } \\
\text { U.S. }\end{array}$ & $\begin{array}{l}\text { NORTH } \\
\text { EAST }\end{array}$ & $\begin{array}{l}\text { NORTH } \\
\text { CENTRAL }\end{array}$ & SOUTH & WEST \\
\hline \multirow{2}{*}{$\begin{array}{l}\text { Have Basement/ } \\
\text { Craw1 Space }\end{array}$} & $\begin{array}{c}\text { Number } \\
\text { (Millions) }\end{array}$ & 44.7 & 9.3 & 13.6 & 14.5 & 7.3 \\
\hline & $\%$ & 77.5 & 87.5 & 90.8 & 69.5 & 65.1 \\
\hline \multirow[t]{2}{*}{ Heated } & $\begin{array}{c}\text { Number } \\
\text { (Millions) }\end{array}$ & 12.7 & 3.6 & 6.5 & 1.5 & 1.1 \\
\hline & $\%$ & 22.0 & 33.6 & 43.2 & 7.2 & 9.9 \\
\hline \multirow{2}{*}{$\begin{array}{l}\text { No Basement/ } \\
\text { Crawl Space }\end{array}$} & $\begin{array}{c}\text { Number } \\
\text { (Millions) }\end{array}$ & 13.0 & 1.3 & 1.4 & 6.4 & 3.9 \\
\hline & $\%$ & 22.5 & 12.5 & 9.2 & 30.5 & 34.9 \\
\hline
\end{tabular}

Source:

Energy Information Administration Office of Energy Markets and End Use

The 1982 Residential Energy Consumption Survey 

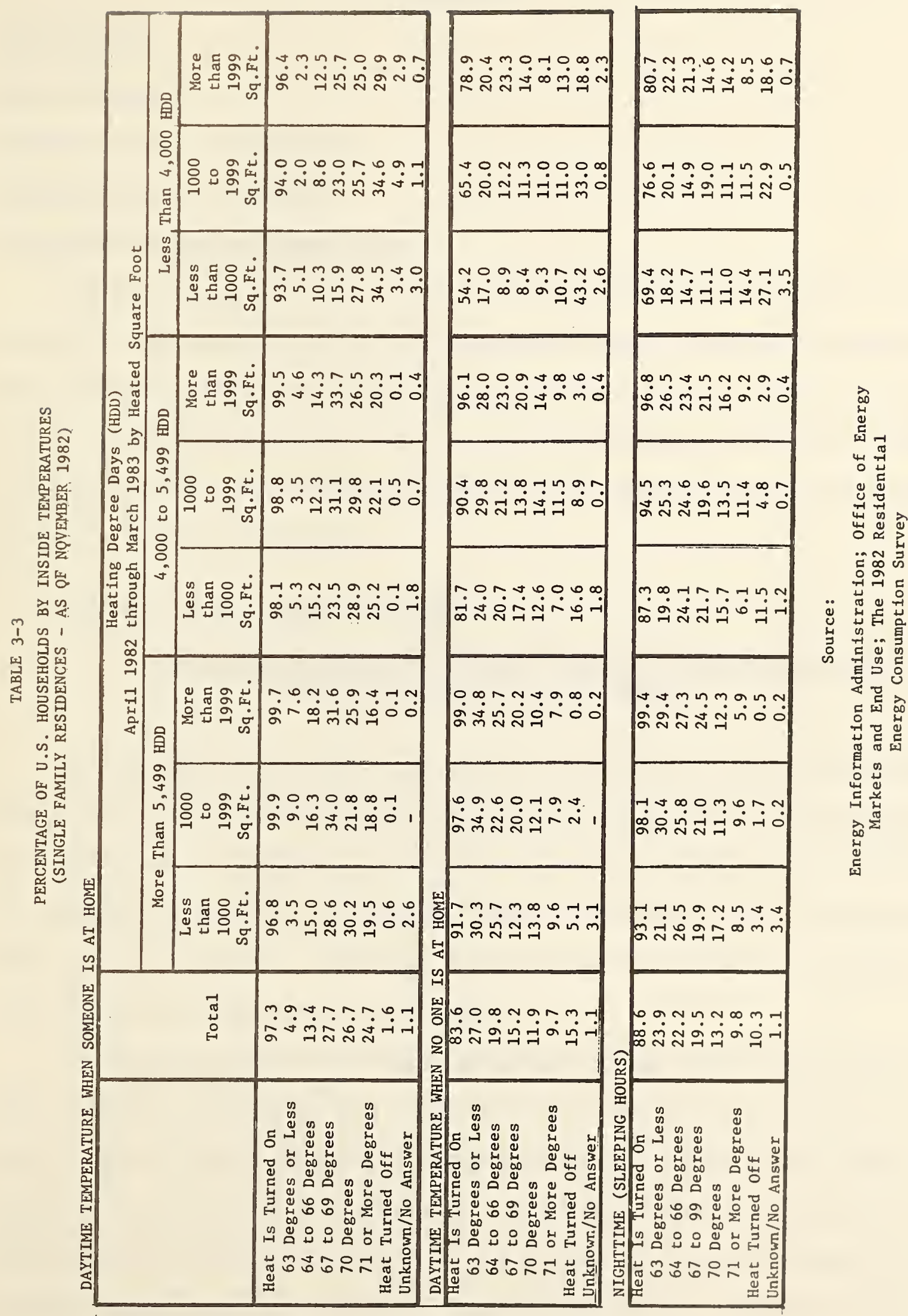

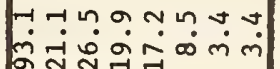

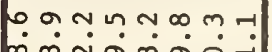

ฌังสำ

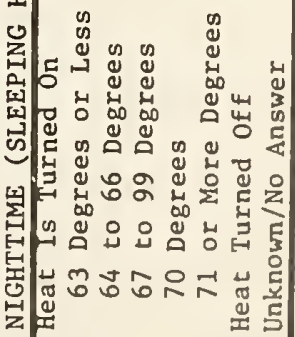





\section{WATER HEATERS}

\section{HOI WATER USAGE}

\section{CURRENI VALUE: $64.3 \mathrm{gal} /$ day}

\section{PRPOSED VALUE: $60 \mathrm{gal} / \mathrm{daY}$}

\section{HISIORICAL BASIS FOR CURRENT VALUE}

The current value for hot water usage was estimated by the National Bureau of Standards [1] not from direct measurements, but from hot-water heater energy usage metered data obtained by several electric and gas utilities and from general service efficiency factors obtained from laboratory tests. The following equation was used to calculate hot water usage by the indirect analysis:

Average hot water usage in gallons =

$$
\frac{\text { (average total energy consumed) } \times \text { (average service efficiency) }}{\text { energy required per gallon heated }}
$$

Using the above equation, the national average hot water usage was calculated to be 64.3 gallons per day, 365 days per year with a nominal tank temperature of $145^{\circ} \mathrm{F}$; input water temperature of $55^{\circ} \mathrm{F}$; and an ambient air temperature of 55\% $\mathrm{F}$. A National Bureau of Standards report, Household Appliance Usage Data [2], describes the basis for the estimate and includes the origin for the data used as follows:

The energy consumed was treated independently for gas and for electric water heaters. The average gas energy of 378 therms per year was taken as the average of the average annual energy consumptions reported for regional usage by five gas utility companies. The average gas heater service efficiency of 47 percent was taken as the average of results of laboratory studies on one gas heater tested by the Institute of Gas Technology and on two gas heaters tested by the Houston Lighting and Power Company. The 
average annual energy consumption for the electric heaters of $6012 \mathrm{kWh}$ per year was taken as the average of the average annual regional energy consumptions reported by 13 electric utility companies. The average service efficiency for the electric heater of 75 percent was taken as the average of results of (a) laboratory tests conducted on one heater by the Institute of Gas Technology and on three heaters by the Bouston Lighting and Power Company, and (b) field tests on 54 metered units by Detroit Edison over two weeks in the summer and two weeks in the winter.

In each separate case-gas and electric--reported results were combined into unweighted averages without regard to sampling methods, locality, manufacturer, size, or specific operating conditions. The data collected in the field were those offered voluntarily by the utility companies and varied widely in format, detail, and estimated reliability. In most instances, the thermostat setting was unknown; and no information was provided on whether the water heaters were usually located outside the house, in unheated cellars, or inside the heated or air-conditioned volumes of housing units. Most of the data were for individual houses, but some were for apartments.

The annual median water surface temperature (as reported by the U.S. Geological Survey) was taken to be the annual average tank water-input temperature for the specific location involved.

In addition, the NBS report states that no direct data are available to support an estimate of uncertainty in national average hot water usage and the magnitude of systematic errors cannot be reasonably estimated because of the diversity of the reported observations. The report correctly addresses the point that the mathematical relationship used (shown at the beginning of this section) is in error on the high side (i.e., gives too large a value of average water use) because it includes an 
additional average of cross-product terms of energy and service efficiency and that the magnitude of the cross-product contribution is unknown. APPROACH FOR UPDATE

The current value of $64.3 \mathrm{gal} /$ day for a national hot water usage factor is a derived value determined indirectly from average energy usage and average service efficiencies, as explained above. In order to revise this value, this update incorporates information developed subsequent to the establishment of the $64.3 \mathrm{gal} /$ day value and evaluates a number of reports that address this topic. Each report is reviewed for methodology, data presented, and conclusions reached and an overall assessment made regarding the adequacy of the current value.

\section{RESULTS AND DISCUSSION}

A report by Ro D. Clear and D. B. Goldstein [3] addresses those factors important in estimating hot water consumption and energy use. The report analyzes the National Bureau of Standards approach and establishes a methodology for determining hot water usage based upon a home inhabited by an average size family with an average appliance usage.

The focus for the Clear and Goldstein report lies with the following algorithm: $W=\left(P+S_{C} C+S_{d} D\right) \times F S$.

$W=$ Daily water usage (gal/day)

$\mathrm{P}$ = Per-capita water use for personal services (showers, hand washing, bathing (gal/day)

$C=$ Per-capita increase in water use caused by the presence of a clotheswasher (gal/day)

$\mathrm{D}$ = Per-capita increase in water use (compared to hand dishwashing) caused by the presence of an automatic dishwasher (gal/day)

$S_{C}=$ Saturation of clothes washers (percentage of families owning a clothes washer)

$S_{d}=$ Saturation of dishwashers (percentage of families owning a dishwasher)

FS = Family size (number of members) 
The above equation assumes a relationship of a simple linear combination of coefficients, all of which are proportional to family size. The authors state that this equation is intuitively plausible and that some data exists to support its accuracy. The authors derive numerical values for each of the parameters and state that for some of the parameters good agreement is achieved when compared to some direct or indirect measurement. The following results are presented:

\section{WATER USAGE PARAMETERS}

Auto Clotheswasher

$$
C=5.6 \pm 1
$$

$$
\mathrm{S}_{\mathrm{C}}=.7 \text { (estimate) }
$$

Wringer Washer

$$
W W=3 \pm 2
$$$$
\mathrm{S}_{w w}=.1 \text { (estimate) }
$$

Dishwasher

$$
\mathrm{D}=3 \pm 1.5
$$

$$
S_{\alpha}=.4 \text { (estimate) }
$$

Personal Use

$$
P(\text { gas })=10.3 \pm 3
$$$$
\mathrm{P}(\text { electric) }=6 \pm 1 \mathrm{P}(\mathrm{avg})=8 \pm 2
$$

Family Size

$$
\text { FS (avg) }=2.8
$$

FS (single family) $=3.2$

Water Use: $\mathrm{w}$

Electric; $W=\left(6+5.6 \times .7+3 x_{0} 1+3 x_{0} 4\right) \times 2.8=11.4 \times 2.8=32 g p d \pm 4$

Gas; $\quad W=(10.3+5.6 \times .7+3 \times .1+3 \times .4) \times 2.8=15.7 \times 2.8=44 \mathrm{gpd} \pm 9$

Average; * $W=(8+5.6 \times .7+3 \times .1 \times 1+3 \times .4) \times 2.8=13.4 \times 2.8=38 \mathrm{gpd} \pm 6$

Average Single Family; $W=13.4 \times 3.2=42 \mathrm{gpd} \pm 7$

* This is not a weighted average of gas and electric households.

$P$ (electric) is far more accurately known than $P$ (gas) and a simple average was used for the estimate of average water use.

In effect, it is concluded that for a family of 3.2 persons, the daily hot water usage would be $42 \mathrm{gpd} \pm 7$.

Although the above is presented with detailed back-up, the accuracy of the results are questionable. The assumption of a simple linear combination of coefficients, all of which are proportional to family size, is unjustified (see ontario Hydro, below). Small variations in nonlinearity and non-proportionality could change the results 
significantly. In addition, the authors question their own values for $P$, the personal use parameter, which provides the largest input to the equation. The report states that the water use for gas water heaters is only supported by two studies, one of them small and the other small and non-random, and concludes that more study is clearly needed to evaluate $P$ more accurately.

The results, however, are considered as another useful data point developed through a different premise from that by which the current 64.3 gal/day was developed. However, neither is based on actual metered water use.

A second report evaluated was prepared by M. Perlman of Ontario Hydro for the American Society of Heating, Refrigerating, and Air Conditioning Engineers, Inc. [4]. The report uses data derived from actual measurements conducted in residences and contains the results of consumer surveys regarding water usage. The field measurements include two years of data for five residences in the Toronto area and one year of data for fifty more residences located throughout the Province of Ontario. The report addresses such items as the overall and peak average hot water usage; the average daily and peak hourly hot water use by family size, average age of adults, presence of children, seasonal variations, etc. The results indicate an overall average hot water use of $62.4 \mathrm{gal} /$ day for all families and a 63.1 gal/day for a "typical family" defined as a family size of 4 (two adults and two children) owning a clothes washer and dishwasher.

In reviewing the data which are thoroughly presented in graphic and tabular form, the non-linearity of the various parameters are manifest. Some of the variables are reported as follows: 
Family Size

$$
\begin{aligned}
& 2 \\
& 3 \\
& 4
\end{aligned}
$$$$
5
$$

Average Daily Use gal/person

Average Daily Hot Water Use By Average Age of Adults

$$
\begin{gathered}
\text { Average Age } \\
\text { of Adults }
\end{gathered}
$$

$$
\begin{gathered}
30 \\
30-35 \\
35-40 \\
40-45 \\
45-50
\end{gathered}
$$

59
Average Daily Use gal/person

This representation, in effect, is counter to the Clear and Goldstein basis that assumes a simple linear combination of coefficients, all of which are proportional to family size.

Regarding the Ontario Hydro value of 63.1 gal/day for the "typical" family, the assumption of a 4 member family is coupled with the demographic survey of the residences which revealed that 988 of the households in ontario had automatic clothes washers and 798 automatic dishwashers. This must be compared to the average United States household numbering 2.7 persons in 1980 [5] and the saturation levels of clothes washers and dishwashers for 1983 as 73.68 and 45.08 respectively [6]. It should be noted that the term "family" refers to a group of two or more persons related by blood, marriage, or adoption and residing together in a household. A "household", however, includes all persons who occupy a "housing unit." (For complete definitions see Statistical Abstract of the United States, National Data Book and Guide Sources, Bureau of the Census.)

In addition to the above, another factor which must be addressed in the average cold water temperature differences between Canada and the United States. Section I of this report, (WATER HEATERS - INLET WATER 
TEMPERATURE), recomends a national average temperature of $58^{\circ} \mathrm{F}$. Using the same source data [7], the average inlet water temperature for the ontario area is at least $10^{\circ} \mathrm{F}$ colder. If it can be assumed that this inlet water temperature also represents the temperature flowing from the cold water tap, a higher hot water use rate will result if this colder inlet water is blended with hot water for showering or other personal use.

In summary, the detailed data and analysis presented by antario Hydro lends high credibility for the 63.1 gal/day water usage for the "typical" family in the Ontario area. Comparable data for the United States, however, showing a smaller number of persons in the average household, fewer clothes washers and dishwashers, and a higher average cold water tap temperature, leads us to conclude that the Canadian data can be viewed as a reasonable upper bound for water temperature usage extrapolated to the United States.

A third report evaluated that contains field data was provided by a study prepared by the Lawrence Berkeley Laboratory [8]. The paper describes and analyzes both laboratory and field test data on water heaters from more thar 75 published and unpublished sources. The report contains a table showing per capita hot water usage from occupied households in various locations in the United States, Denmark, and Canada. The pertinent data only for the United States are shown below: 


\section{PER CAPITA HON WATHR USAGE (GAT/DAY)}

Daily Hot Water

Average No. Number of Use Per Capita Building Fuel Project of occupants Units (Gallons) Type Iype Location

\begin{tabular}{|c|c|c|c|c|c|}
\hline 2.8 & 8 & 12.2 & SF & $\mathrm{E}$ & Tacoma, WA \\
\hline 4.0 & 1 & 13.0 & SF & $E$ & Chico, CA \\
\hline 4.0 & 1 & 15.5 & SF & $E$ & Chico, CA \\
\hline 4.0 & 13 & 17.1 & SF & G & San Diego, CA \\
\hline 3.3 & 18 & 17.7 & SF & $\mathbf{E}$ & Portland, OR \\
\hline 4.7 & 23 & 17.7 & SF & S & San Diego, CA \\
\hline 4.0 & 85 & 18.3 & SF & $\mathrm{E}$ & USA \\
\hline 3.6 & 10 & 28.7 & SF & $\mathrm{E}$ & Portland, OR \\
\hline 2.9 & 15 & 19.7 & SF & $\mathbf{S}$ & USA \\
\hline 2.9 & 32 & 21.7 & SF & $\mathrm{E}$ & $M D, V A, W V$ \\
\hline 3.7 & 10 & 22.7 & SF & $\mathbf{E}$ & $\mathrm{PA}$ \\
\hline 2.9 & 12 & 22.9 & SF & 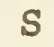 & San Diego, CA \\
\hline 3.7 & 23 & 23.9 & SF & $\mathrm{E}$ & Seattle, WA \\
\hline 3.6 & 251 & 18.54 & & & \\
\hline
\end{tabular}

In reviewing the above table, a number of observations can be made. If the daily water use per capita (18.54 gal/day) is multiplied by the average number of occupants (3.6), the daily usage is $66.7 \mathrm{gal} /$ day. If the daily water use per capita (18.54 gal/day), however, is multiplied by the average number of persons per household in the United States (2.7), the daily water use falls to $50.1 \mathrm{gal} / \mathrm{day}$. In addition, if the number of occupants is weighted by number of units and per capita use (since the high daily water use per capita also corresponds to the larger number of units) a per capita use of $19.6 \mathrm{gal} /$ day is derived and when multiplied by the average number of persons per household (2.7) a total consumption of $53.0 \mathrm{gal} /$ day results. Finally, assuming that the average family size in a single-family dwelling is 3.2 people [3], the daily usage is either 59.3 or 62.7 gallons if the daily water use per capita is 18.54 or 19.6 gallons per day, respectively. Of course, it should be noted that the 251 units sampled are still small in number and not geographically dispersed to give very special meaning to the results. On the other hand, the data and results cannot be ignored. 
A review of the information presented above shows that both the analytical approach and the limited field data available suffer from lack of definitive data on a nationwide basis. The analytical approach of Clear and Goldstein offers a daily water usage of 42 gallons; the antario Hydro studies show results of 63.1 gallons for a Canadian scenerio; and the Usbelli study varies between 66.7 and 50.1 gallons. The daily usage rate, based on the Usibelli study, varies between 59.3 and 62.7 gallons, if the average family size of 3.2 in a single-family dwelling is used. Further, in weighing all of the studies together it could be reasonably concluded that the current 64.3 gallons per day factor for a national hot water usage may be an upper limit and a lower value may be more representative. In this regard, a proposed value of 60 gallons per day may be more desirable as it would move the value closer to an "integrated assessment" and also not imply the measure of accuracy that the current 64.3 gallon per day value suggests. It is, therefore, recommended that the current value for hot water usage be changed from 64.3 to 60 gallons per day until a better body of field data is gathered and a more definitive usage factor determined.

\section{REFERENCES}

[1] National Bureau of Standards; "Test Procedure Review - Water Heaters"; Washington, D.C.; April 2.1, 1977.

[2] Alan D. Davies, et. al; "Household Appliance Usage Data"; NBSIR 801994: National Bureau of Standards; Washington, D.C.; dated February 1980 (Final Report issued March 1980).

[3] R. D. Clear and D. B. Goldstein; "A Model for Water Heater Energy Consumption and Hot Water Use: Analysis of Survey and Test Data on Residential Hot Water Heating"; Iawrence Berkeley Laboratory Report 10797: Berkeley, CA; Revised May 2, 1980. 
[4] M. Perlman; B. E. Mills; and B. T. Barber; "Development of Residential Hot Water Use Patterns"; RP-430; Prepared for American Society of Heating, Refrigerating, and Air-Condition Engineers, Inc. by ontario Hydro; Toronto, Ontario; Decenber 1984.

[5] General Housing Characteristics; United States Summary; 1980 Census of Housing; HC80-1-AI; Bureau of the Census; U.S. Department of Commerce; Issued May 1983.

[6] Appliance Magazine; A Dana Chase Publication; "The Saturation Picture"; September 1984.

[7] J. F. Blakey; "Temperature of Surface Waters in the Conterminous United States"; U.S. Geological Survey Hydologic Investigations Atlas HA-235; Washington, D.C.; 1966.

[8] A. Usibelli; "Monitored Energy Use of Residential Water Heaters Buildings Energy - Use Compilation and Analysis: Part D"; Report No. LBL-17873; Buildings Energy Data Group; Lawrence Berkeley Laboratory; Berkeley, CA; dated May 1984. 
SECTION V

\section{EURNACES}

\section{QUIDOOR DESIGN TEMPERATURE}

\section{CURRENT VALUE: 5 F F}

\section{PROPOSED VALUE: $17^{\circ} \mathrm{F}$}

\section{HISTORICAL, BASIS FOR CURRENT VALUE}

Test methods were developed for furnaces in $1978[1,2]$ in support of Public Law 94-163 which required the Federal Energy Administration to carry out energy conservation activities related to the efficiencies of household appliances. As part of the development of test procedures for furnaces, a national average value for heating load hours per year was needed which included the value of a National outdoor design temperature (see SECIION IV - FURNACES - HEATING LOAD HOURS.

As reported in the Household Appliance Usage Data [3], the current outdoor design temperature of $5^{\circ} \mathrm{F}$ was calculated as a weighted average of long-term "97.5\%-design dry-bulb temperatures" at weather stations in the lower 48 states supplied by the Armed Forces [4]. The "97.5\% winter design dry-bulb temperature" is defined as temperatures which have been equaled or exceeded by $97.5 \%$ of the total hours in the months of December, January, and February (a total of 2160 hours). In a normal winter, there would be approximately 54 hours at or below the $97.5 \%$ value [5]. The weighting was by the number of housing units using gas or oil as their primary heating fuel as reported by the 1970 census, but it is unknown how the regions were delineated or how much of the population was not included in the calculation.

This factor is primarily used in the equation to compute heating load hours (see SECTION IV - FURNACES - HEATING LOAD HOURS). The factor is 
discussed herein separately to present, in detail, the methodology and data used to confirm the current value or develop a new proposed value. Further, by including this factor as a separate section of this report, the value is highlighted for use in other building related energy studies requiring a National average outdoor design temperature.

\section{APPRDACH FOR UPDATE}

The approach taken here for estimating the National average outdoor design temperature is similar to that for estimating annual average water heater inlet temperature (see SECTION I - WATER HEATERS - INLET WATER TEMPERATURE). This means that the average outdoor design temperature will be weighted for each State by its housing population. Specifically, average "97.5\%-design temperatures" were estimated for each State using data for climatic conditions for the United States as tabulated in the ASHRAE Handbook of Fundamentals [5]. This information was weighted by the number of single-family housing units for that State derived from 1980 census data [6] and an overall National average outdoor design temperature determed.

Estimating average state outdoor design temperatures was subjective. An alternative would have been to weight the temperature reported for each locale by the population of that locale. However, this would have frequently meant neglecting populous regions. For example, no weather station is listed for Montgomery County, Maryland, which is one of the most populous counties of the state and contains the state's second largest city. In the method used here, Montgomery County, which is a suburb of Washington, DC, was assigned a design temperature equal to that of Washington, DC, and was considered in calculating the average state outdoor design temperature. 
Table 5-1 shows the results of the outdoor design temperature calculation. The resulting housing population-weighted average outdoor design temperature was $16.7^{\circ} \mathrm{F}$, considerably higher than the presently used ${ }^{\circ} \mathrm{F}$ value. Although a certain amount of subjectivity is involved in estimating state average outdoor design temperatures, the National average outdoor design temperature should change little even allowing for differences in individual assessments. As indicated above, all populous areas were included even if they were not represented by a weather station in the ASHRAE Fundamentals [5].

We cannot fully explain the large difference between our result, 16.70F, and the current value of 50F. Part of this could be due to the shift of population to warmer climates between 1970 and 1980. Further differences could be attributed to the different methodologies used since the current value is weighted by housing units having gas- or oil-fired heating systems, while the proposed value uses single-family houses. In addition, the current value and the proposed value are based on different weather-station data and different regions over which temperatures were averaged. It is quite possible that temperatures simply cannot be meaningfully estimated for areas located between two weather stations, and large population areas are recessarily neglected no matter how much one tries to include them.

\section{RECOMMENDATIONS}

The replacement of the current $5^{\circ} \mathrm{F}$ value with a $17^{\circ} \mathrm{F}$ value for a National average outdoor design temperature seems justified. The basis for the justification is the relatively high confidence placed in the methodology and the data used. It is again noted that this new value is used in the equation to compute heating load hours (see SECTION VI - 
FURNACES - HEATING LOAD HOURS) and may also be used in other building related energy studies requiring a National average outdoor design temperature.

\section{REFERENCES}

[1] "Test Procedures for Conventional Ranges, Conventional Cooking Tops, Conventional Ovens, Microwave Ovens and Microwave/Conventional Ranges, Furnaces and Vented and Unvented Home Heating Equipment"; Federal Register 43, 91; 20108-20205 (May 10, 1978).

[2] "Proposed Test Procedures for Furnaces; Public Hearing"; Federal Register 42, 155; 40826-40845 (August 11, 1977).

[3] Davis, A.D., et al.i "Household Appliance Usage Data"; NBSIR 80-1994, National Bureau of Standards, Washington, DC; February 1980.

[4] Departments of the Air Force, Army, and Navy, "Engineering Weather Data," AFM-99-8, June 15,1967.

[5] American Society of Heating, Refrigerating and Air-Conditioning Engineers, Inc., "ASHRAE Handbook, 1981 Fundamentals," Atlanta, 1981.

[6] U.S. Department of Commerce; "1980 Census of Housing Volume 1, Characteristics of Housing Units; Chapter A, General Housing Characteristics; Part 1, United States Summary"; Bureau of the Census; Issued May 1983. 
TABIE 5-1

BOOSING POPULATION-WEIGEIPD AVERAGE OUTDOOR WINILRR DESIGN TEEMPERATURE

\begin{tabular}{|c|c|c|}
\hline SIPTE & $\begin{array}{l}\text { ASSUMED } \\
\text { 97.5\% WINHER } \\
\text { DESIGN DRY BULB } \\
\text { TEDPERAIURE OF }\end{array}$ & $\begin{array}{l}\text { EOUSIAG FOPULATION } \\
\text { (IN THOUSANDS) } \\
1980 \text { CENSUS } \\
\text { SINGE FAMTIY DIITS }\end{array}$ \\
\hline $\begin{array}{l}\text { Alabama } \\
\text { Alaska } \\
\text { Arizona } \\
\text { Arkansas } \\
\text { Califomia }\end{array}$ & $\begin{array}{l}21 \\
21 \\
33 \\
20 \\
41\end{array}$ & $\begin{array}{r}1,168 \\
86 \\
745 \\
725 \\
6,440 \\
\end{array}$ \\
\hline Colorado & 1 & 835 \\
\hline Connecticut & 7 & 794 \\
\hline Delaware & 14 & 170 \\
\hline District of Columbia & 17 & 127 \\
\hline Florida & 42 & 2,798 \\
\hline Georgia & 22 & 1,525 \\
\hline •Hawaii & 63 & 198 \\
\hline Idaho & 10 & 272 \\
\hline Illinois & 2 & 2,699 \\
\hline Indiana & 2 & 1,655 \\
\hline Iowa & -5 & 902 \\
\hline Ransas & 5 & 775 \\
\hline Rentucky & 10 & 1,045 \\
\hline Louisiana & 33 & 1,195 \\
\hline Maine & -2 & 295 \\
\hline Maryland & 17 & 1,145 \\
\hline Massachusetts & 9 & 1,257 \\
\hline Michigan & 6 & 2,721 \\
\hline Minnesota & -12 & 1,128 \\
\hline Mississippi & 25 & 732 \\
\hline Missouri & 7 & 1,518 \\
\hline Montana & -16 & 222 \\
\hline Nebraska & -3 & 493 \\
\hline Nevada & 20 & 203 \\
\hline New Bampshire & -1 & 235 \\
\hline New Jersey & 14 & 1,710 \\
\hline New Mexico & 13 & 347 \\
\hline New York & 12 & 3,096 \\
\hline North Carolina & 21 & 1,761 \\
\hline North Dakota & -19 & 174 \\
\hline Ohio & 5 & 3,119 \\
\hline Oklahoma & 13 & 1,010 \\
\hline Oregon & 24 & 812 \\
\hline Pennsylvania & 11 & 3,415 \\
\hline Rhode Island & 9 & 221 \\
\hline South Carolina & 26 & 883 \\
\hline South Dakota & -10 & 200 \\
\hline Tennessee & 18 & 1,373 \\
\hline Texas & 30 & 4,143 \\
\hline Utah & 8 & 372 \\
\hline Vermont & -8 & 135 \\
\hline Virginia & 18 & 1,554 \\
\hline Washington & 26 & 1,225 \\
\hline West Virginia & 10 & 577 \\
\hline Wisconsin & -5 & 1,321 \\
\hline Wyoming & -7 & 118 \\
\hline
\end{tabular}

Population-weighted National Average Winter Design Temperature $\left({ }^{O}\right.$ ) .

16.7

* Not included in calculation. 



\section{EURNACES}

\section{ANNUAL HEATTNG LOAD HOURS}

\section{CURRENT VALUE: 2080 Hours Per Year}

PROPOSED VALUE: 2080 Hours Per Year

\section{HISTORICAL BASIS FOR CURRENT VALUE}

Test methods were developed for furnaces in $1978[1,2]$, in support of Public Law 94-163 which required the Federal Energy Administration to carry out energy conservation activities related to the efficiencies of household appliances. As part of the development of test procedures for furnaces, a national average value for heating load hours per year was needed [2]. A study made on Household Appliance Usage Data [3] describes the analytical approach used to determine the current value for furnace annual heating load hours and is based upon the following equation:

Annual Heating Load Hours =

$$
\frac{\text { Degree-days per year } \times 24 \text { hre per day } \times \text { SHL }}{\text { (Balance Point Temp. - Outdoor Design Temp.) x SHL }}
$$

where: $\quad$ SHL $=$ heat loss rate of the structure in Btu per hour per degree Fahrenheit

The current value was derived as follows:

Annual Heating Load Hours $=2080=$ $\frac{5200 \text { Degree-days per year } \times 24 \mathrm{hr} \text {. per day }}{\left(65^{\circ} \mathrm{F}-5^{\circ} \mathrm{F}\right)}$

The calculation that produced the current value of 2080 heating load hours per year used 5200 degree-days; a balance point of $65^{\circ} \mathrm{F}$; and a $5^{\circ} \mathrm{F}$ outdoor air design temperature. These were based on weighted averages using long-term weather data and 1970 census data. The $65^{\circ} \mathrm{F}$ temperature used as the balance point (zero heat point) is the traditional reference 
temperature for computing degree-days, and marks the outdoor dry bulb temperature boundary between a load and no load on the heating system. The Household Appliance Usage Data Study [3] further states that the rate of conduction and infiltration is, for practical purposes, considered proportional to the difference between indoor and outdoor temperatures. The number of degree-days in a day at a given location is computed by finding the arithmetic average of the high and low temperatures for the day and subtracting the result from the balance point $\left(65^{\circ} \mathrm{F}\right)$. No heating degree-days are counted if the average is above the balance point. When summed over the heating season, the total degree-days for a year is proportional to the annual heating load. In addition, the conductive heat loss characteristics of a given structure may also be included in the annual heating load hour calculation, but since these characteristics appear in the numerator and denominator of the equation (see above), they cancel out and may be dropped for brevity.

APPROACH FOR UPDATE

As a first step, this update addresses the $65^{\circ} \mathrm{F}$ balance point and its use in deriving the current value for annual heating load hours. A review was made of currently marketed heating equipment [4], systems design practices [5], and housing construction practices [6] in order to reveal any appropriate changes to the original assumptions used in the calculation of the current value. The second step in the update addresses the calculation of average degree-days based upon a housing population weighting. This information, along with the revised outdoor design data, which is also based upon a housing population weighting, (see SECTION V FURNACES - OUTDOOR DESIGN TEMPERATURE) is incorporated into the Annual Heating Load Hour equation and a new value determined.

RESULTS AND DISCUSSION

The function of the heating load hours parameter is to combine certain climate and indoor factors into a form that is concise and convenient for 
analytical uses, while meeting the requirement for a representative national value. The $65^{\circ} \mathrm{F}$ balance point, a reference used in the analytical equation to combine climate and indoor factors, has been of concern to the furnace manufacturing community, [1]. This community has at times stated that this balance point is no longer representative of current home construction and heating practices and leads to serious overestimates.

An analysis by NBS [3] also revealed areas of uncertainty with regard to the use of $65^{\circ} \mathrm{F}$ as a balance point. Historically, the $65^{\circ}$ balance point temperature was proposed [7] in the $1920^{\circ} \mathrm{s}$ as a result of study by a gas utility company. In their analysis [3], NBS pointed out that several changes since that date indicate that a re-examination of that balance point would be in order. Residential construction is considerably tighter, reducing heat losses from air infiltration; much more insulation is being used, reducing heat losses by conduction through the walls and ceilings; and there are many more heat releasing appliances in homes, reducing the additional heat requirements from furnaces. NBS also states in this analysis that higher fuel costs are encouraging the use of lower thermostat settings during the heating season. Further, because of heat storage characteristics of house structures and contents, transient excursions of outdoor air temperatures below $65^{\circ} \mathrm{F}$ may result in no call for heat from the central heating system for as long as 6 to 12 hours.

DOE has recognized the general nature and effects of the factors listed above, but has deferred any change from the $65^{\circ} \mathrm{F}$ balance point until deeper study reveals a better alternative [3]. However, the lack of precision with regard to the assumptions used to determine furnace energy use can have a major impact on the resulting heating load hours per year value. NBS has estimated [3] that the effect of a change of one degree fahrenheit in either the indoor temperatures (an indoor design temperature of $70^{\circ} \mathrm{F}$ was used in determining the present value), or the balance point temperature $\left(65^{\circ} \mathrm{F}\right)$ at 5200 degree-days is approximately $900 / 5=180$ degrec- 
days. The corresponding effect on the heating load hours per year would be approximately 72 hours per degree F. After reviewing related heating and weather data [5, 8], NBS recommended and DOE accepted an adjustment factor, C, of 0.77 as a multiplier for changing the burner operating hours to the approximate heating load experienced by the system.

A survey of data compiled by industry [9, 10] and professional research communities $[11,12,13]$ revealed that there is as yet no field data comprehensive enough to replace analytical data in areas of: indoor control temperatures, including any setback temperatures and durations; and design point temperatures, incluaing local variations relative to the reference weather station. Because of the above, along with the realization that there is a large accumulation of data based on a long institutionalized $65^{\circ} \mathrm{F}$ balance point, no recommendation is made here to change this value. Requirements for the determination of burner operating hours (not studied here) should be based on a reassessment of the $c=0.77$ (adjustment) factor rather than a recomputation of degree-days using a different balance point.

In addition to reviewing the degree-day basis, as noted above, the methodology for determining a national average degree-day value was also evaluated. Instead of using the data for degree-days at the weather stations selected to represent the various states, a housing population weighted degree-day average was calculated.

The study used data of yearly heating degree days as distributed in the conterminous United States which was found in the 1980 U.S. Climatic At las produced by NOAA [14]. Degree day values were given for at least four population centers in every State. A degree-day value for each State was determined by averaging the values of these centers, giving weight to housing population åistribution.

Although the above method is subjective in that judgement was required to select a representative value for average degree days by State, 
nevertheless, it is felt that a fair assessment has been made and that the selected values would vary by a small amount even in those cases where there is room for other assessments. Such differences should not, therefore, significantly alter the overall results.

Also important to this study is the location of the Nation's population of single-family housing units. This was determined by the use of the 1980 census data [15]. The census divides single-family housing units by State. These are the same housing population values used to determine the updated outdoor design temperature value. (See SECTION V FURNACES - OUTDOOR DESIGN TEMPERATURE) The above information resulted in a weighted national average yearly value of 4232 degree-days (see Table 61).

The annual heating load hours may now be recalculated using the following values in the equation: 4232 annual degree-days (as derived above); $65^{\circ} \mathrm{F}$ as the balance point (no change); and $17^{\circ} \mathrm{F}$ as the average outdoor design temperature (as determined in SECTION VI - FURNACES OUTDOOR DESTGN TEMPERATURE).

Annual Heating Load Hours $=2116=$

\section{Degree-days per Year $\times 24$ hr. per day $\left(65^{\circ} \mathrm{F}-17^{\circ} \mathrm{F}\right)$}

It should be noted again that the annual average degree-day value (4232) and the average outdoor design temperature $\left(17^{\circ} \mathrm{F}\right)$ are both derived using housing population weighted data and consequently, will shift with population migrations.

RECOMMENDATIONS

In viewing the annual heating load hours (2116) derived through the methodology using housing population weighted data, and comparing this value with the current value of 2080 heating load hours per year, little change is noted. This may indicate that a consistent approach in determining the annual degree-days and average outdoor design tenperature 
will result in little change in determining annual heating load hours. In view of the small difference between the two values (approximately 1.7\%), it is recommended that the current value of 2080 heating load hours be retained.

REFERENCES

[1] "Test Procedures for Conventional Ranges, Conventional Cooking Tops, Conventional Ovens, Microwave Ovens and Microwave/Conventional Ranges, Furances and Vented and Unvented Home Heating Equipment"; Federal Register 43, 91; 20108-20205 (May 10, 1978).

[2] "Proposed Test Procedures for Furnaces; Public Hearing"; Federal Register 42, 155; 40826-40845 (August 11, 1977).

[3] Davis, A.D., et al.; "Household Appliance Usage Data"; NBSIR 80-1994, National Bureau of Standards, Washington, DC; February 1980.

[4] 1984 Sweets Catalog; Heating Equipment; McGraw Hill; New York.

[5] ASHRAE Handbook of Fundamentals, 1980.

[6] National Association of Homebuilders; Washington, DC.

[7] American Gas Association; House Heating; 1930.

[8] Departments of the Air Force, Army, Navy; Engineering Weather Data; (AFM-88-8); June 15, 1967.

[9] Mr. J. Griffin; Edison Electric Institute; Washington, DC.

[10] Mr. J. Langmead; GAMA.

[11] Nelson, L.W.; "Reducing Fuel Consumption with Night Setback"; ASHRAE Journal; August 1973.

[12] The Code for Energy Conservation in New Building Construction; National Conference of States on Building Codes and Standards; December 1977.

[13] Energy Conservation in New Building Design; Standard 90A-80; ASHRAE; 1980 .

[14] U.S. Climatic Atlas; NOAA; 1980. 
[15] U.S. Department of Commerce; 1980 Census of Housing; Volume I; Detailed Housing Characteristics; Equipment and Plumbing Facilities for States; Part 1; United States Summary. 
TARLE 6-1

Eousing Population Weighted Average Annual Degree Days

\begin{tabular}{|c|c|c|}
\hline SHATE & $\begin{array}{l}\text { BOUSING POPOLAIION } \\
\text { (IN ILEOSANDS) } 1980 \\
\text { CWNSUS SINELE FANTIY } \\
\text { UNTIS }\end{array}$ & $\begin{array}{l}\text { DEGREA DAYS } \\
\text { (AVHRAGE PER YEAR) }\end{array}$ \\
\hline $\begin{array}{l}\text { Alabama } \\
\text { Arlzona } \\
\text { Arkansas } \\
\text { Callfornia } \\
\text { Colorado }\end{array}$ & $\begin{array}{r}1168 \\
748 \\
725 \\
6440 \\
835\end{array}$ & $\begin{array}{l}2400 \\
3300 \\
3300 \\
2800 \\
6300\end{array}$ \\
\hline Connecticut & 794 & 5900 \\
\hline Delaware & 170 & 4900 \\
\hline District of $\mathrm{C}$. & 127 & 4200 \\
\hline Florida & 2798 & 2100 \\
\hline Ceorgia & 1525 & 2400 \\
\hline Idaho & 272 & 6100 \\
\hline Illinois & 2699 & 5800 \\
\hline Indlana & 1655 & 5700 \\
\hline Iowa & 902 & 6800 \\
\hline Ransas & 755 & 5300 \\
\hline Kentucky & 1045 & 4900 \\
\hline Iouisianna & 1195 & 3300 \\
\hline Maine & 295 & 8600 \\
\hline Maryland & 1145 & 4700 \\
\hline Massachusetts & 1257 & 6500 \\
\hline Michigan & 2721 & 7400 \\
\hline Minnesota & 1128 & 8900 \\
\hline Mississippl & 732 & 2200 \\
\hline Missour1 & 1518 & 4900 \\
\hline Montana & 222 & 8000 \\
\hline Nebraska & 493 & 6600 \\
\hline Nevada & 203 & 6100 \\
\hline New Bampahlre & 235 & 10600 \\
\hline Now Jersey & 1710 & 4800 \\
\hline Now Mexico & 347 & 4600 \\
\hline New York & 3096 & 6200 \\
\hline North Carolina & 1761 & 3300 \\
\hline North Dakota & 174 & 9300 \\
\hline Ohio & 3119 & 5800 \\
\hline aklahoma & 1010 & 3800 \\
\hline Oregon & 812 & 5300 \\
\hline Pennoylvanla & 3415 & 5500 \\
\hline Rhode Island & 221 & 5900 \\
\hline South Carolina & 883 & 2300 \\
\hline South Dakota & 200 & 7800 \\
\hline Tennessee & 1373 & 4000 \\
\hline Texas & 4143 & 1900 \\
\hline Otah & 372 & 6100 \\
\hline Vermont & 135 & 8200 \\
\hline Virginia & 1554 & 3800 \\
\hline Washington & 1225 & 5400 \\
\hline West Virginia & 577 & 4800 \\
\hline Wisconsin & 1321 & 7800 \\
\hline Wyoming & 118 & 7600 \\
\hline
\end{tabular}

National Average Yearly Degree Days

4232 


\section{POOM ATR CONDIITONERS}

\section{YEARTY HOURS OF USE}

\section{SURRENT VALUE: 750 Hours Per Year}

\section{PROPOSED VALUE: 670 Hours Per Year}

\section{HISTORICAL BASIS FOR CURRENI VALUE}

Test methods were developed for room air conditioners in 1976 [1], [2], in support of Public Law 94-163 which required the Federal Energy Administration to carry out energy conservation activities related to household appliance efficiency. These test methods were developed at the National Bureau of Standards (NBS) with cooperation from the Association of Home Appliance Manufacturers (AHAM) and in conjunction with the ANSI Standard 2234.1-1972 (AHAM-RAC-I) for Room Air Conditioners. The methods NES developed were based upon an analytical approach which was used to calculate the estimated national average hours of use for room air conditioners.

NBS [3] used a report by David A. Pilati of Oak Ridge National Laboratory as a starting point. This Pilati report [4], estimates the annual compressor operating hours for ten cities using selected weather years. The author modified the National Bureau of Standards' Load Determination (NBSLD) computer program to calculate compressor operating hours while also accounting for the ability of natural ventilation to provide cooling. The assumptions were that a house room air conditioner was set at $78^{\circ} \mathrm{F}$ and the windows were opened if the outdoor conditions could maintain the inside temperature between $75^{\circ} \mathrm{F}$ and $78^{\circ} \mathrm{F}$. Compressor hours for ten cities were averaged using census data and market saturation data [5] as weighting factors. Average air conditioning demand hours were also calculated using the same data (demand hours being defined in this study as 
the larger of two numbers: hours of dry bulb temperature above $80^{\circ} \mathrm{F}$, or wet bulb temperature above $67^{\circ} \mathrm{F}_{\text {。 }}$ ) The required weather data were obtained from the Engineering Weather Data Manual AFM 88-8 [6]. The ratio of compressor hours to demand hours then gave the percent of time that the room air conditioner compressor was operating per demand hour.

The National Bureau of Standards used this modified program to then compute the annual national average air conditioning demand hours value. This average was weighted for population and market saturation using the same weather [6] and market saturation data [5] used in the Pilati study [4]. Average hours of air conditioner operation were computed for 138 Standard Metropolitan Statistical Areas (SMSA's). From this work, the estimated national average of 730 hours of compressor operating time was computed and rounded up to the 750 value.

The study, Household Appliance Usage Data [7], describes this analytical approach and also cites 750 hours as the national average number of hours of compressor operation per year for room air conditioner units. This same study also states that the usage factor of 750 hours per year is based entirely on analyses and assumptions and that field surveys are advisable in order to verify the factor. Such field survey data would account for the impact of thermostat settings, the oversizing or undersizing of air conditioner units and also account for ventilation use patterns. It is assumed that users of room air conditioners, unlike consumers who cool with central air conditioners, are more inclined to open windows when the outdoor air speed and temperature are adequate to maintain comfortable indoor temperature. Ventilation can make a substantial difference in the cooling required by air conditioners, thus affecting hours of use. Also, the great differences in hours of room air conditioner usage from one locality of the country to another would impact a national 
average usage factor if field data were used to determine regional values.

Early progress reports of field tests by AHAM [8] were mentioned in the Household Appliance Usage Data report [7], but at that time testing was considered too incomplete to be useful input. Since the AHAM study is now complete [9], it appears that field survey data is available that is sufficient to check against the calculation method which established the initial factor.

\section{APPRQACH FOR UPDATEE}

The approach for this update focused upon field data available with regard to annual hours of operation for room air conditioners since the establishment of the current value of 750 hours. Two manufacturers of room air conditioners, York and Carrier, were contacted as well as various trade and professional associations including: the Air Conditioning Contractors of America (ACCA), The Association of Home Appliance Manufacturers (AHAM), The Air Conditioning and Refrigeration Institute (ARI), and the Edison Electric Institute (EEI). In addition, The American Society of Heating, Refrigerating and Air Conditioning Engineers (ASHRAE), Oak Ridge National Laboratory (ORNL), and Lawrence Berkeley Laboratories (LBL) were contacted in an attempt to obtain field data. It was found through discussion with room air conditioning manufacturers [10], and trade and professional associations [11], [12], [13], that the final AHAM Report [9] was used as a basis for recent research done by these organizations [14], [15]. This AHAM report is also the basis for this current study. In effect, data from the AHAM study which shows yearly hours of use of room air conditioners as distributed in the conterminous United States, is adjusted by room air conditioner saturation, by state, to arrive at a national average. 
The AHAM report was the result of an extensive field survey whose major objective was to provide sufficient room air conditioner field test data on compressor operating hours per year for correlation with a calculation method also developed by AHAM. Data were taken from AHAM field testing sites, throughout the United States, in over 30 locations with major emphasis on New York City, Chicago, St. Iouis, and Dallas. Data for a total of over 290 units were collectea. Another source of data for the AHAM Report was the field testing results collected and published by other organizations $[16,17$, and 18].

As part of the AHAM report a map was developed which shows yearly hours of operation for room air conditioners as distributed in the conterminous United States [19]. This map shows bands of operating hours for room air conditioners with each band spread generally representing a change of 250 yearly hours of operation.

Using the AHAM map (Fig. 7-1), a single representative number of hours of operation was estimated for each state (Table 7-1). Where a single band covers a State, the midpoint of the band was used. Where more than one band covers a state, an average number of hours of operation for the state was not assigned solely on the geographic distribution of the bands within the State, but was based on the room air conditioners saturation within the state. For example, if a state was covered by two bands, a uniform room air conditioners saturation would lead to selection of the boundary value of the two bands. If, however, the centers of population were generally located within one of the two bands, the number of hours within that band was selected to represent the average number of hours of room air conditioner operation for that state. 
The above method is subjective in that judgement was required to select a representative value for hours of operation for each State. Nevertheless, it is felt that a fair assessment has been made and that the selected values would vary by a small amount even in those cases where there is room for other assessments of individual state hours of operation of room air conditioners. Such differences, therefore, should not significantly alter the overall results.

Also important to this study is the location of the Nation's population of room air conditioning units. This was determined by the use of the 1980 census data [20] (Table 7-1) in that the census survey of equipment and plumbing facilities also includes individual room air conditioning units by state. It should be noted that no information is provided regarding the number of room air conditioners per dwelling unit or air conditioner size.

The above information permitted the calculation of a weighted National average for the number of hours of operation of room air conditioning units. The average number of operation hours for room air conditioners by State was multiplied by the number of units in that State; the products added; and then divided by the total number of room air conditioning units. From these calculations, the average room air conditioning hours of operation, weighted by room air conditioner saturation, is 668 . RECOMMENDATIONS

In consideration of the information presented above, a National average number of annual hours of operation for room air conditioning units of 670 hours is recommended. Although this recommended figure varies to some degree from the current value of 750 hours, the variance is less when viewed fron. the perspective that the original computation for the current value was calculated at 730 hours and later rounded up to 750 hours. This 
factor should be reviewed if significant changes in field data or census data occur or if other information is developed that has the potential to provide further refinement.

\section{REFERENCES}

[1] Federal Agency Administration; "Test Procedures for the Energy Conservation Program for Appliances (Room Air Conditioners)"; Federal Register 41, 145; 31237-31239 (July 27, 1976).

[2] "Test Procedures for Room Air Conditioners" (Final); Federal Register 42, 105; 27896-27899 (June 1, 1977).

[3] Hung, HoK.; Estimating Annual Hours of Use of Room Air Conditioners, a memorandum to S. Fischler of the Product Systems Analysis Division, National Bureau of Standardjs; Washington, DC; February 20, 1976.

[4] Pilati, D.A.; Room Air-Conditioner Lifetime Cost Considerations; Annual Operating-Hours and Efficiency; ORNL-NSF-EP-85; Oak Ridge National Laboratory; Oak Ridge, Tennessee.

[5] Billboard Publications, Inc.; Merchandising Week; February 24, 1975.

[6] Departments of the Air Force, Army, Navy; Engineering Weather Data; (AFM 88-8); June 15, 1967.

[7] Household Appliance Usage Data; NBSIR 80-1994; Alan D. Davies, et. al.; February 1980 (Final Report Issued March 1980).

[8] Weizeorick, J.T.; A letter to S. Fischler; NBS; Progress Report on The AHAM ROOM Air Conditioner Hours of Operation Program; Association of Home Appliance Manufacturers; (AHAM); August 16, 1976.

[9] Beard, W.J.; Hours of Operation for Room Air Conditioners; Association of Home Appliance Manufacturers, (AHAM); September 1978.

[10] Larry Rathensburger; York Air Conditioners; Harrisburg, PA.

[11] J. Griffin; Edison Electric Institute; Washington, DC. 
[12] J.T. Weizeorick, Paul Growman; Association of Home Appliance Manufacturers; Chicago, IL.

[13] Dick Denny; Air Conditioning and Refrigeration Institute; Arlington, virginia.

[14] York; 1982; Publication \$2041.

[15] Edison Electric Institute; 1978; "Air Conditioning Usage Study"; \$782.

[16] "Energy Efficiency Program for Room Air Conditioners, Central Air Conditioners, Dehumidifiers, and Heat Pumps"; Science Applications, Inc.; Prepared for DOE under Contract No. CR-04-60724-00; La Jolla, CA; March 1978.

[17] "Manual J: Load Calculation for Residential Winter and Summer Air Conditioning"; National Environmental Systems Contractors Association; Arlington, Virginia, 1975.

[18] "Application Guide: Weatherton (R) Heat Pump Seasonal Performance Factor (SPF) Calculation Guide"; Publication No. 22-3050-l; General Electric; Louisville, Kentucky; April, 1975.

[19] "AHAM ROom Air Conditioner HOURS OF OPERATION"; Association of Home Appliance Manufacturers, (AHAM); June 1980.

[20] U.S. Department of Commerce; "1980 Census of Housing Volume 1, Detailed Housing Characteristics, Equipment and Plumbing Facilities for States, Part 1, United States Sumary." 


\section{AHAM \\ ROOM AIR CONDITIONER \\ AVERAGE COMPRESSOR HOURS OF OPERATION \\ PER YEAR}

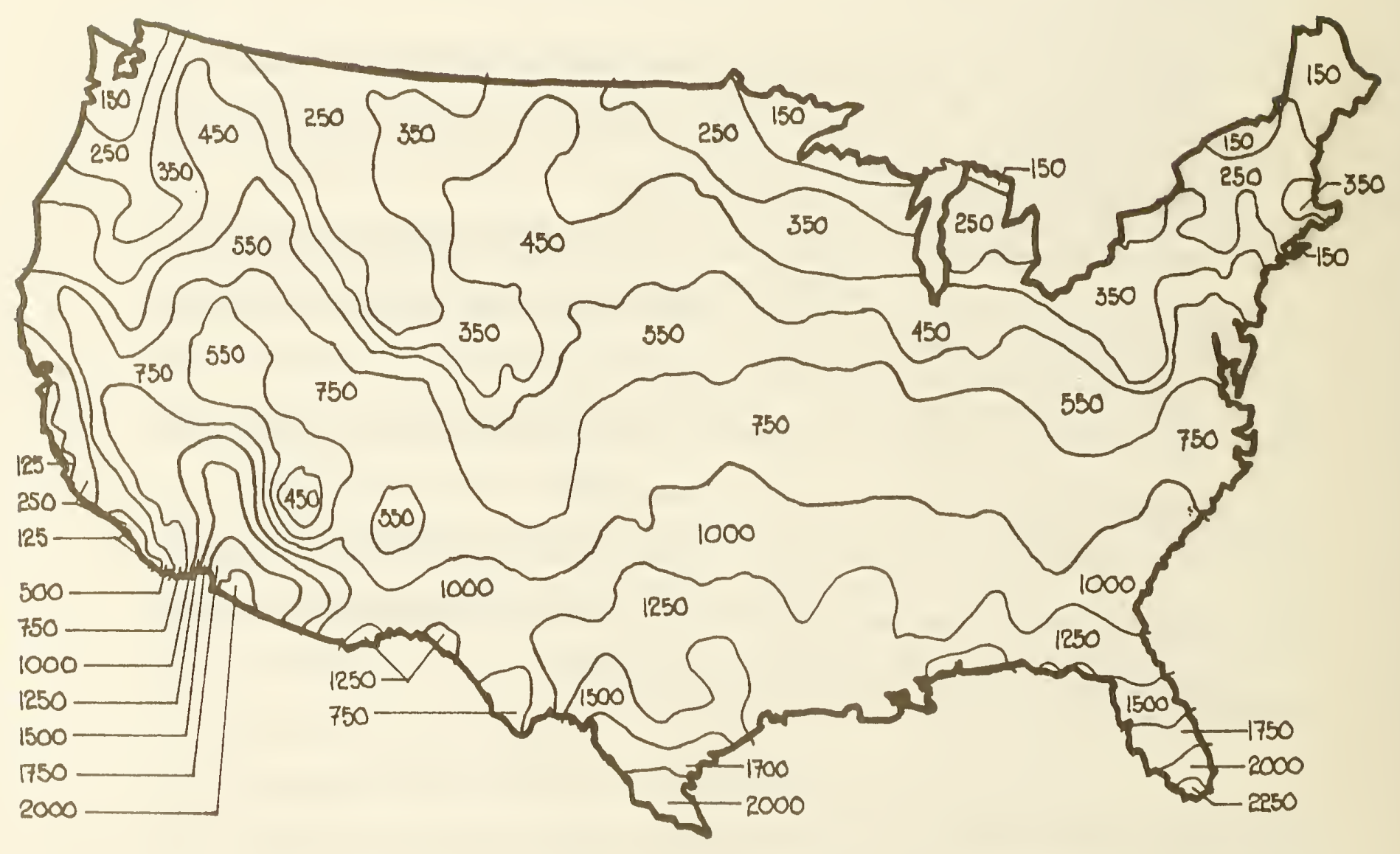


POPULATION-WEIGHTED AVERAGE HOURS OF OPERATION FOR ROOM AIR CONDITIONER UNITS

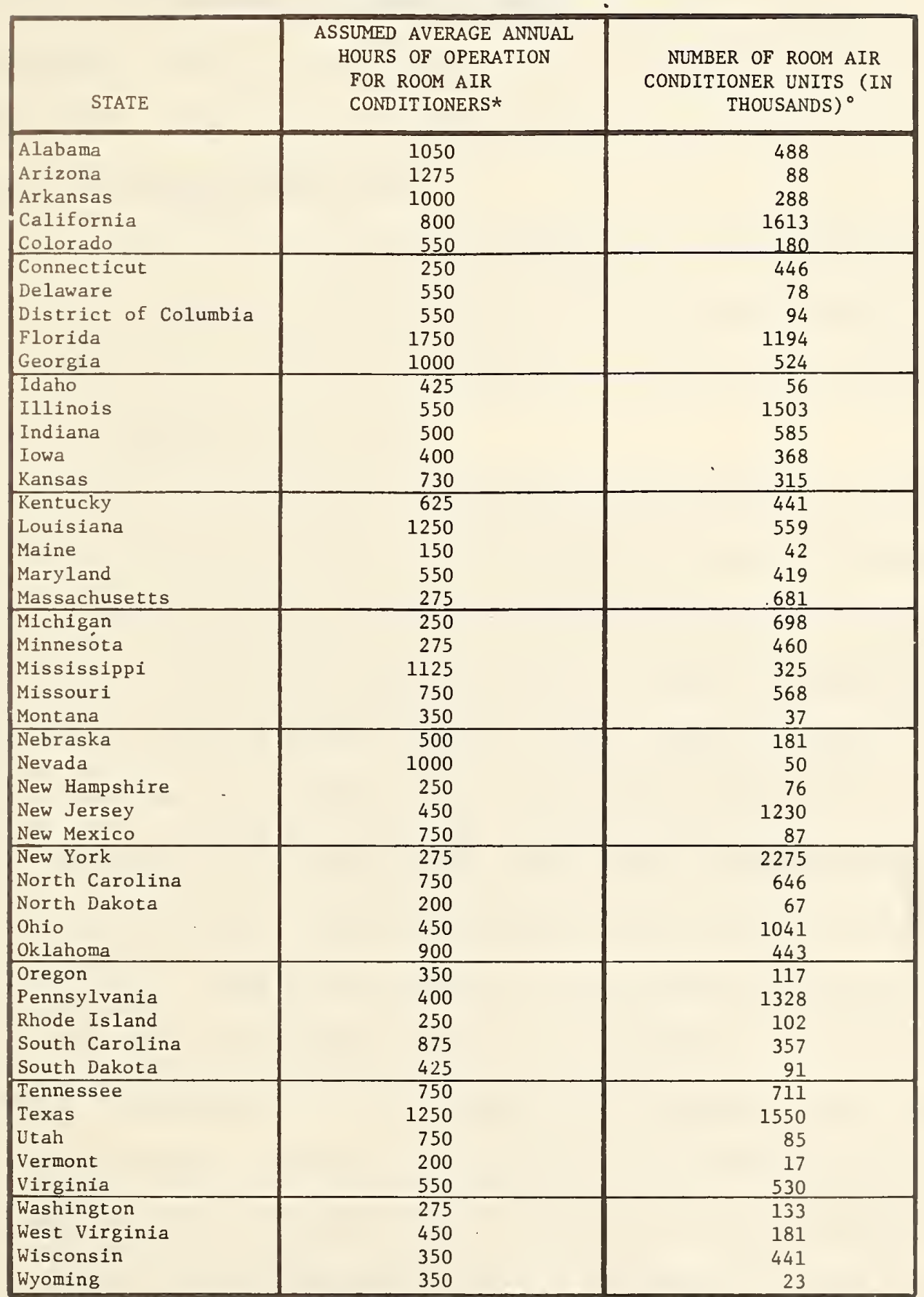

Population-weighted National average hours of operation for Room Air Conditioning Units.

* Association of Home Appliance Manufacturers, 1984.

- U.S. Housing Census, 1980 

SECTION VIII

CENTRAL AIR CONDITIONERS*

ANNUAL FUIL LOAD COMPRESSOR OPERATING HOURS

CURRENT VALUE: 1000 Hours Per Year

PROPOSED VALUE: 1150 Hours Per Year

HISTORICAL BASIS FOR CURRENT VALUE

Test methods were developed for central air conditioners in 1977 [1] and 1978 [2] in support of Publ ic Law 94-163 which required the Federal Energy Administration to carry out energy conservation activities related to household appliance efficiency.

In order to develop the current value for central air conditioner annual hours of operation (full load compressor operating hours), three approaches were compared. The first involved a study by Pilati [3] who used a value of 750 annual operating hours for room air conditioners (see SECTION VII - ROOM AIR CONDITIONERS - YEARLY HOURS OF USE) to derive a value for central air conditioners. He assumed that users of room air conditioners will tend to use natural ventilation to achieve their cooling objectives when outdoor conditions permit, while users of central air conditioners will tend to avoid natural ventilation during the cooling season. Data from the "ASHRAE Handbook of Fundamentals," American Society of Heating, Refrigerating and Air Conditioning Engineers, 1972, were used in a multi-variable regression analysis to extend the results over the country and to produce "predictions" for ten cities and the results were cross-plotted. The calculations using this method yielded a result of approximately 1100 hours per year. A second study was made by Honeywell [4] who reported the results of compressor-hours analysis for 26 cities (six of which coincided with Filati's selections) using weather data from

* Including heat pumps operating in the cooling mode. 
the Departments of the Air Force, Army, and Navy. These data included the mean number of hours per year for which the dry bulb temperature was observed in each of a succession of five-degree bins. Compressor operating hours for an unventilated house were estimated for three temperature control methods. Averages among the six cities coinciding with Pilati's selection show a value of 1518 annual hours.

The third method, developed by the National Bureau of Standards, is based upon the same weather data used in the Foneywell study. The results from this approach are considered to be more approximate than the previous two because of the methods of data aggregation. The average number of hours in each temperature bin were first combined by state and then weighted by the number of housing units with central air conditioning by State (derived from the 1970 U.S. Census of Housing Summary $\mathrm{BC}(1) \mathrm{Bl}$.), to develop nationally averaged bin-hours. The compressor was assumed to be off for outdoor temperatures below the balance point and to operate continuously for temperatures at and above a temperature determined by the design point and any system oversizing. A linear relationship with respect to outdoor temperature was used to estimate the fraction of operating time for conditions between these two temperatures. Assuming a $78^{\circ} \mathrm{F}$ set point, a $68^{\circ} \mathrm{F}$ balance point, a $95^{\circ} \mathrm{F}$ design point and a ten percent oversizing factor, a value of 1238 compressor operating hours per year results. Use of a $65^{\circ} \mathrm{F}$ balance point yields 1373 hours.

Statistical information provided by industry on usage patterns in specific locations of the country showed evidence that no single value for usage could be usefully regarded as "representative" even within a limited climate area over more than one cooling season. It was also concluded by NBS [5] that the effects of clinate variation across the nation contribute further to usage varjation. Weather variations from season to season were also stated to contribute uncertainties. NBS, therefore, recomended that 
the annual usage factor be heavily rounded to avoid undue impression of applicability in all situations. The value of 1000 compressor hours per year was recommended because it was believed to be reasonably close to analytical results and because it would provide a convenient basis for calculations if a form of regional treatment is considered in the future.

The study, Household Appliance Usage Data, [6] commented that this usage factor was based entirely upon analyses and assumptions. It was stated that field data, oversizing practices, consumer practices regarding ventilation, temperature objectives, and shutoff periods should be investigated.

\section{APPRQACH FOR UPDATE}

The general approach for this update is to review the most current information available on central air conditioner hours of use [7] and a National average determined by weighing the available data by central air conditioner saturation as published by the Census Bureau [8] for 1980. Data are presented and analyzed using a set point temperature at a constant $75^{\circ} \mathrm{F}$; a normal set point of $75^{\circ} \mathrm{F}$ with an adjustment to the set point to $80^{\circ} \mathrm{F}$ from 5:00 a.m. to 4:00 p.m॰; and a constant thermostat set point of $78^{\circ} \mathrm{F}$. In addition, the current value of 1000 annual full load compressor hours is reevaluated using 1980 Census Bureau data [8] to determine central air conditioner saturation on a state-by-state basis in order to establish a single National value. Heat pumps operating in the cooling mode have also been included to reflect their increasing popularity as a combination heating and cooling appliance.

\section{RESULTS AND DISCUSSION}

Three approaches were used in developing a value for annual compressor operating hours. Two assumed an indoor thermostat constant set point of $78^{\circ} \mathrm{F}$; the third approach assumed a constant $75^{\circ} \mathrm{F}$ set point. All of the approaches assumed that there was no natural ventilation. It was assumed 
that users of central air conditioning will tend to avoid natural ventilation during the cooling season. In these approaches, the compressor was assumed to be off for outdoor temperatures below the balance point and to cycle, as appropriate, for temperatures at and above a temperature determined by the design point and any system oversizing. In the NBS document, Test Frocedure Review - Central Air Conditioners [5], it was determined that one characteristic of the bin calculation methods used in this analysis concerms all outöoor tenperature excursions into the cooling demand region. These contribute to the total compressor hours, however brief they may be or whenever they may occur during the year. However, there are practical reasons for adjusting these theoretical results. Because of the thermal masses of walls and building contents, indoor temperatures do not respond immediately or fully to short-term outdoor temperature fluctuations. Operating hours would also be reduced by any tendencies to confine system usage to the main cooling season. Also, no allowance is made in the analyses for conservation-motivated setbacks during vacations or other perioäs of absence. Thus, it was recommended in this review, that some downward adjustment of theoretical results was warranted.

of the three approaches used, the Honeywell study [4] found that a one-degree increase in indoor temperature decreases the operating hours by an estimated 3\%. A study published in the ASHRAE Journal [7], reveals a savings in compressor hours of operation of $8-20 \%$ by setting the thermostat to $80^{\circ} \mathrm{F}$ during the day and $75^{\circ} \mathrm{F}$ at night as compared to a constant $75^{\circ} \mathrm{F}$ set point. This reflects a practice employed by those households in which all family members are absent from the house during the day. The study also showed a 16-33\% savings in conpressor hours of use with a thermostat setting of $78^{\circ} \mathrm{F}$ constant setpoint versus the $75^{\circ} \mathrm{F}$ set point. This practice is the one most appropriate to a majority of households in which family 
members are at home during the day. Both energy conserving setback practices are becoming increasingly popular in homes with central air conditioning and should be taken into consideration if the average annual number of compressor operating hours is to reflect realistic conditions.

These accepted set point practices, along with the concern expressed earlier for response to regional differences, led to the methodology for this update study. It was decided that an air conditioner saturationweighted average of yearly hours of use be determined for each of the set point practices described above. Sources of data for these studies were the ASHRAE Journal 1976 study previously cited [7] and the 1980 census data [8], which lists the number of central air conditioners for single family residences by State.

The first map used (see Fig. 8-1) shows yearly hours of operation for central air conditioners in single family housing in the conterminous United States when the set point temperature is a constant $75^{\circ} \mathrm{F}$. This map shows bands of operating hours for central air conditioners. From 1000 hours to 3000 hours, the bands have a 200 hour spread; from 1000 hours to 300 hours the bands have a 100 hour spread. The second and third maps (Fig. $8-2 ; 8-3$ ) show yearly hours of savings from the hours shown on the first map for central air conditioners (Fig. 8-1) when two different temperature settings are used. Figure 8-2 indicates the compressor operating hours saved per year when the thermostat is increased to $80^{\circ} \mathrm{F}$ from 5:00 a.m. to 4:00 p.m. and set back to $75^{\circ} \mathrm{F}$ the rest of the time. Figure 8-3 shows the compressor operating hours saved per year when the thermostat is set up to a constant $78^{\circ} \mathrm{F}$. Both of these maps (Fig. 8-2; 83) show bands of saved operating hours for central air conditioners; the bands having a 25 hour spread in the lower range and a 50 hour spread in the upper range. 
For each map, a single representative number of hours of operation was estimated for each state. In Figure 8-2 and 8-3, these hours were yearly hours of operation saved over those hours in Figure 8-1. For each map, where a single band covers a state, the midpoint of the band was generally used. Where more than one band covers a state, an average number of hours of operation, or saved hours of operation, for that state was not assigned solely on the geographic distribution of the bands within the state, but was based on the central air conditioner saturation distribution. For example, if a state was covered by two bands, a uniform central air conditioner saturation would lead to a selection of the boundary value of the two bands. If, however, the central air conditioner saturation favored one of the two bands, the number of hours within that band was selected to represent the average yearly number of hours of operation or hours of operation saved for central air conditioners for that state.

The above method is subjective in that judgement was required to select a representative value for hours of operation for each State. Nevertheless, it is felt that a fair assessment has been made and that the selected values would vary by a small amount even in those cases where there is room for other assessments of individual state hours of operation of central air conditioners. Such differences should, therefore, not significantly alter the overall results.

The hours of operation saved in each state as a result of moving the thermostat to the $80^{\circ} \mathrm{F}$ set point and the constant $78^{\circ} \mathrm{F}$ set point were then subtracted from the yearly average hours of operation for central air conditioners at the $75^{\circ} \mathrm{F}$ set point for each state. Average yearly hours of operation were then 1 isted for each set point by State. (See Tables 8-1; $8-2$; and $8-3$. 
Using this information and the 1980 census data [8] in which the census of equipment and plumbing facilities includes the saturation of individual central air conditioning systems and heat pumps by State, a calculation was performed which derived a weighted National average number of hours of operation of central air conditioners, heat pumps, and total units for each of the accepted set points. For each set point, the average number of hours of central air conditioning operation per State was multiplied by the number of units in that state; the products were added; and divided by the total number of central air conditioning units. (See Tables $8-1$; 8-2; and 8-3.)

From these calculations, the central air conditioning unit populationweighted average number of hours of operation at a $75^{\circ} \mathrm{F}$ constant set point is 1548 hours; at $75^{\circ} \mathrm{F}$ varying the set point to $80^{\circ} \mathrm{F}$ from 5:00 a.m. to 4:00 p.m. is 1383 hours; and at a $78^{\circ} \mathrm{F}$ constant set point is 1286 hours. (See Table 8-5.)

In further reviewing the basis for the current value, it appears that the value is basea on "equivalent annual full load compressor hours." Unfortunately, the documentation covering this subject has been found to be inconsistent in usage and nomenclature. Terms such as "hours of full loaả compressor operation per year" and "hours/year" are used. As such, it should be pointed out that the information presented above is based on the ASHRAE Journal, June 1976 [7] data and is clearly compressor operating hours. The results have been included in this study for completeness, further reference, and later use in extrapolating full load compressor hours.

A conversion from annual compressor operating hours to equivalent annual full load hours was made by the York Division, Borg-Warner Corporation and was based on the annual compressor operating hour information published in the ASHRAE Journal, June 1976 [7]. The results, 
which are mapped as iso-annual ful 1 load hours, are contained in the NBS report Method of Testing, Rating, and Estimating the Seasonal Performance of Central Air-Conditioners and Heat Pungs operating in the cooling Mode [9], and effectively reduce the ASHRAE annual compressor operating houra by ten percent. The cooling load hour map contained in the NBS report is reproduced here as Figure 8-4.

Utilizing the same methodology as described above for annual compressor operating hours, and using 1980 Census Bureau Data, a State-byState analysis was made and a single National value detemined for annual full load operating hours based on a $75^{\circ} \mathrm{F}$ set point. In addition, annual full load operating hours for a $75^{\circ} \mathrm{F}$ set point (increased to $80^{\circ} \mathrm{F}$ from 5:00 a.m. to 4:00 pomo) and a constant $78^{\circ} \mathrm{F}$ set-point were also determined by interpolation using the ASHRAE Journal computations for annual compressor operating hours. The resulting annual full load operating hours at a $75^{\circ} \mathrm{F}$ constant set point is 1319 hours; at $75^{\circ} \mathrm{F}$ varying the set point to $80^{\circ} \mathrm{F}$ from 5:00 a.m. to $4: 00$ p.m. is 1178 hours; and at a $78^{\circ} \mathrm{F}$ constant set point is 1286 hours. (See Table 8-5.) RECOMMENDATIONS

In viewing the summary data presented in Table 8-5, attention is directed to the full load compressor operating hours shown for the $75^{\circ} \mathrm{F}$ set point; the $75^{\circ} \mathrm{F}$ set point $\left(80^{\circ} \mathrm{F}\right.$ from 5:00 a.m. to $4: 00$ p.m. $)$; and the $78^{\circ} \mathrm{F}$ set point. The highest number of annual full load operating hours is 1319 at the $75^{\circ} \mathrm{F}$ set point. However, under energy and cost savings conditions, raising the set point for the day, or part of a day, lowers the annual full load compressor operating hours. If it can be reasonably assumed that the reduced set point temperature is a widely accepted practice throughout the nation and more representative of current usage, the National average for annual full load compressor operation operating hours should reflect this condition. As such, it is recommended that a new value of 1150 hours be 
accepted as the current National average for the annual full load compressor operating hours; this figure not being refined further to suggest a degree of accuracy not warranteo by tlie data and methodology used. This value should be reviewed if significant field data are obtained, if major changes occur in central air condtioner saturation, if the 1976 ASHRAE data are updated, or if other information is ceveloped that has the potential to provide further refinement.

\section{REFERENCES}

1. Federal Energy Administration, "Test Procedures for Central Air Conditioners" (Final); Federal Register 42, 227; 60250-60257; (November 25, 1977).

2. Federal Energy Administration; "Test Procedures for Central Air Conditioners; Corrections"; Federal Register 43, 108; 24268-24269; (June 5, 1978).

3. "Room Air Conditioner Lifetime Cost Consideration: Annual operating Hours and Efficiencies;" Pilati, David A.; Oak Ridge National Laboratory; October 1975.

4. "Reducing Energy Consumption Luring the Cooling Season - an Analog Computer Study;" Honeywell Corporation Report 70-6245; Septenber 1974.

5. National Bureau of Standards; Test Procedure Review - Central Air Conditioners; July 12, 1977.

6. National Bureau of Standards; "Household Appliance Usage Data"; NBSIR 80-1994; Davies, A. D., et al.; February 1979.

7. McConnell, Tobias, and Nelson; "Reducing Energy Consumption During the Cool ing Season"; ASHRAE Journal; June 1976.

8. U.S. Department of Commerce; "1980 Census of housing, Volume I, Detailed Housing Characteristics, Equipment and Plumbing Facilitjes for States, Part 1; United States Sumary." 
9. Method of Testing, Rating and Estimating the Seasonal Performance of Central Air-Conditioners and Heat Pumps Operating in the Cooling Mode; NBSIR 77-1271; G.E. Kelly and W.H. Parken, Jr.; Apri.l 1978; National Bureau of Standards; Washington, DC 20234. 
Figure 8-1

\section{COMPRESSOR HOURS PER YEAR AT $75^{\circ} \mathrm{F}$ SET POINT *}

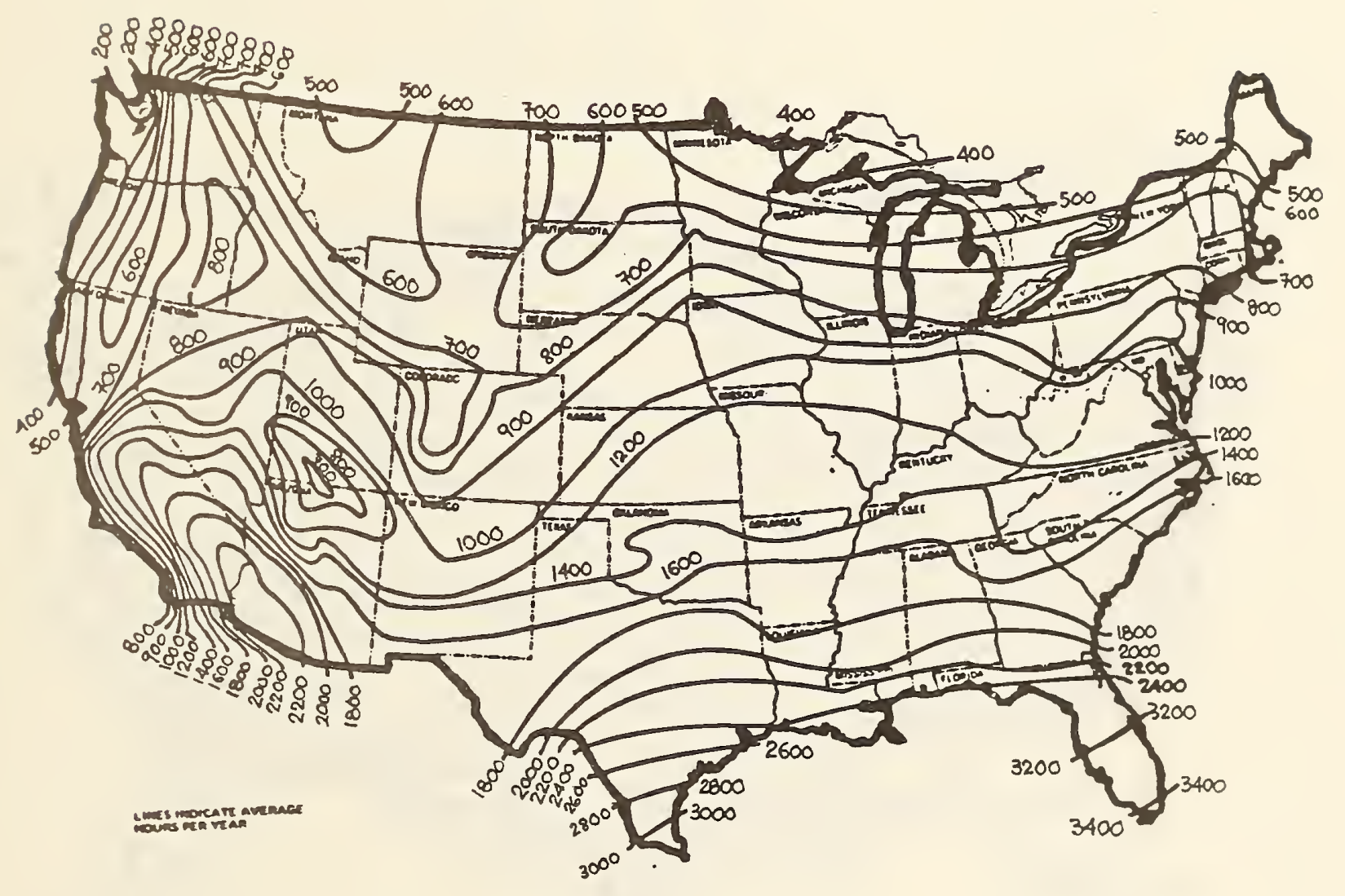

* ashrae journal, JuNe 1976. 
Figure 8-2

\section{COMPRESSOR HOURS SAVED PER YEAR AT DAY SETUP OF $80^{\circ} \mathrm{F}$ FROM 5A.M. TO 4P.M. **}

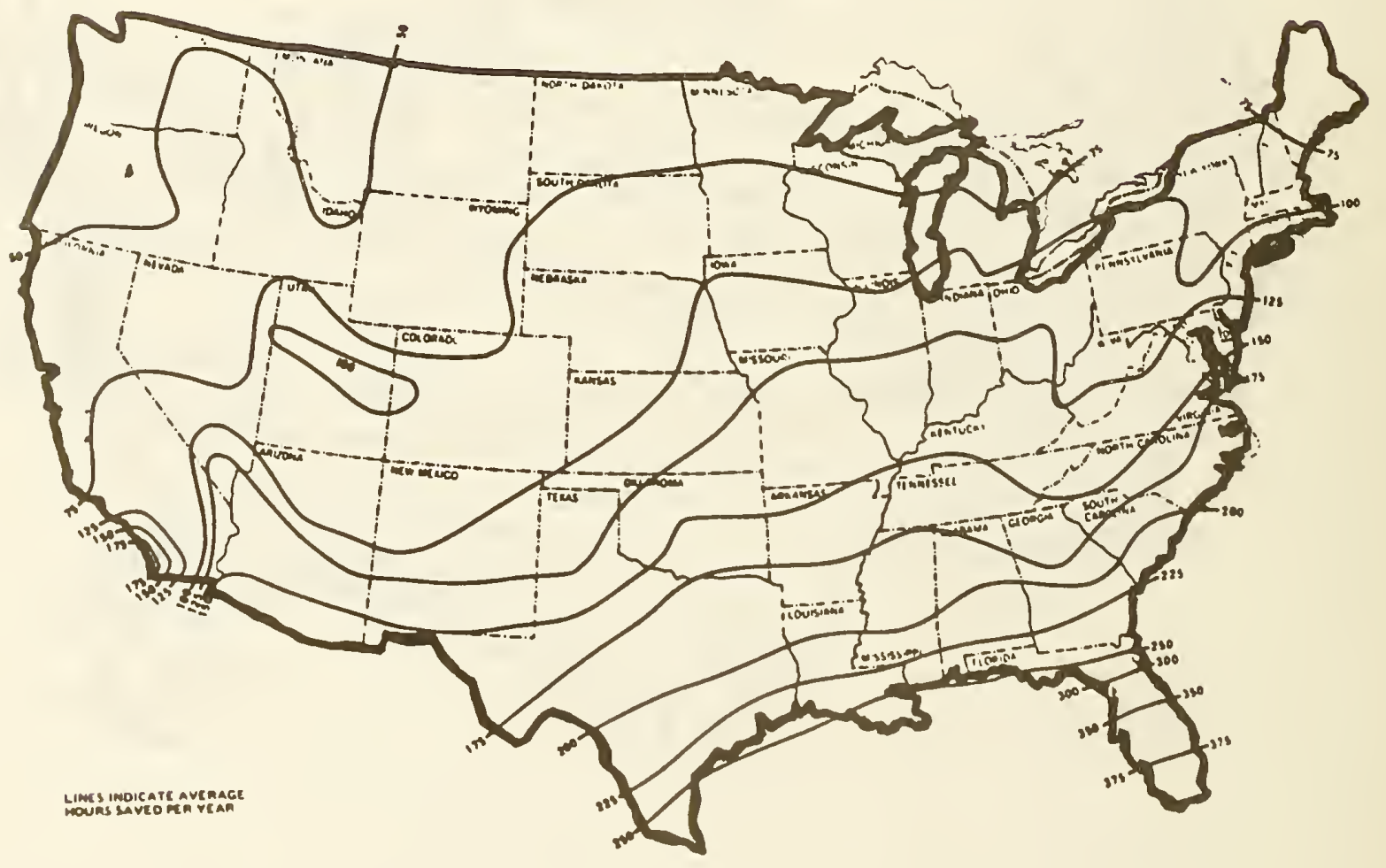

* ashrae courall, uUme 1976. 


\section{COMPRESSOR HOURS SAVED PER YEAR ATA CONSTANT $78^{\circ} \mathrm{F}$ SET POINT *}

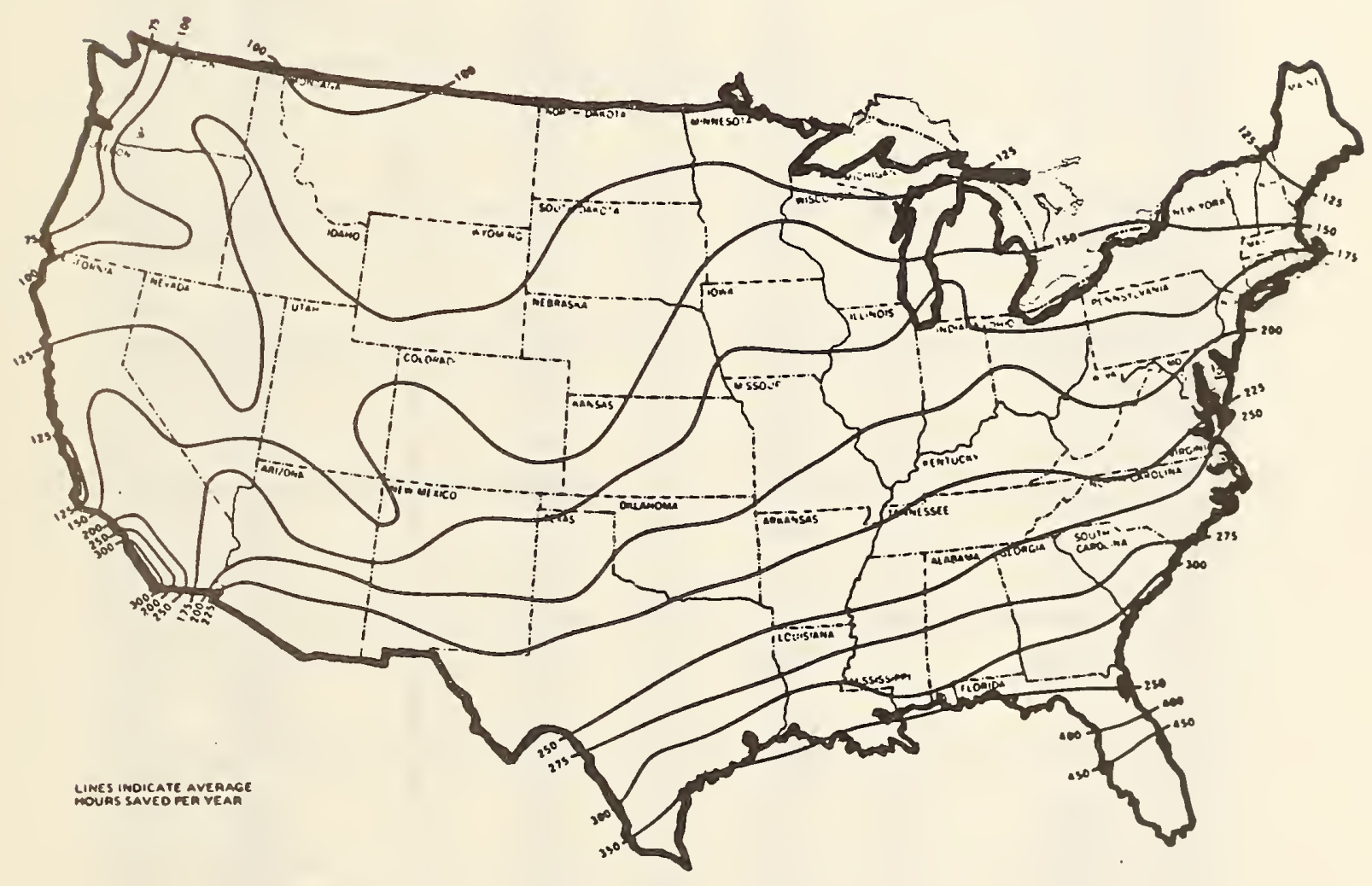

* ashraE Jouryal, JUTE 1976. 
Table 8-1

CENIRAL AIR CONDITIONER ANMUAL COMPRESSOR HOURS OF OPERATTON AT 75\%F SET POINT

\begin{tabular}{|c|c|c|c|}
\hline state & $\begin{array}{l}\text { Bousing } \\
\text { Population } \\
\text { (In thousands) } \\
\text { Baving Central } \\
\text { Air Conditioners } \\
\text { (1980 Census) }\end{array}$ & $\begin{array}{l}\text { bousing } \\
\text { Population } \\
\text { (in thousands) } \\
\text { Having Heat } \\
\text { Pumps } \\
\text { (1980 Census) }\end{array}$ & $\begin{array}{l}\text { Average Number of } \\
\text { Compressor Bours } \\
\text { Per Year at } 75^{\circ} \text { F } \\
\text { Set Point (ASHRAE } \\
\text { Joumal, June 1976) }\end{array}$ \\
\hline $\begin{array}{l}\text { Alabama } \\
\text { Arizona } \\
\text { Arkansas } \\
\text { California } \\
\text { Colorado }\end{array}$ & $\begin{array}{r}531 \\
674 \\
346 \\
2084 \\
179 \\
\end{array}$ & $\begin{array}{r}103 \\
160 \\
29 \\
169 \\
17 \\
\end{array}$ & $\begin{array}{r}1875 \\
1975 \\
1575 \\
975 \\
750 \\
\end{array}$ \\
\hline Connecticut & 87 & 19 & 800 \\
\hline Delaware & 71 & 6 & 1000 \\
\hline District of Columbia & 92 & 7 & 1100 \\
\hline Florida & 2399 & 648 & 3125 \\
\hline Georgia & 805 & 88 & 1750 \\
\hline Idaho & 60 & 19 & 725 \\
\hline Illinois & 1351 & 65 & 950 \\
\hline Indiana & 625 & 66 & 1075 \\
\hline Iowa & 372 & 22 & 875 \\
\hline Ransas & 430 & 14 & 1225 \\
\hline Rentucky & 396 & 80 & 1175 \\
\hline Louisianna & 704 & 35 & 2250 \\
\hline Maine & 3 & 5 & 500 \\
\hline Maryland & 667 & 70 & 1100 \\
\hline Massachusestts & 109 & 31 & 750 \\
\hline Michigan & 484 & 25 & 450 \\
\hline Minnesota & 286 & 17 & 550 \\
\hline Mississippi & 307 & 33 & 1900 \\
\hline Missouri & 808 & 36 & 1300 \\
\hline Montana & 25 & 5 & 550 \\
\hline Nebraska & 296 & 11 & 950 \\
\hline Nevada & 186 & 34 & 1825 \\
\hline New Bampshire & 8 & 5 & 650 \\
\hline New Jersey & 511 & 40 & 900 \\
\hline New Mexico & 209 & 6 & 1100 \\
\hline New York & 481 & 51 & 750 \\
\hline North Carolina & 680 & 199 & 1300 \\
\hline North Dakota & 34 & 7 & 550 \\
\hline Chio & 891 & 151 & 1000 \\
\hline Oklahoma & 559 & 26 & 1500 \\
\hline Oregon & 85 & 45 & 500 \\
\hline Pennsylvania & 539 & 84 & 950 \\
\hline Rhode Island & 13 & 3 & 700 \\
\hline South Carolina & 407 & 128 & 1625 \\
\hline South Dakota & 65 & 9 & 725 \\
\hline Tennessee & 574 & 141 & 1525 \\
\hline Texas & 3016 & 158 & 2225 \\
\hline Utah & 150 & 8 & 950 \\
\hline Vermont & 1 & 2 & 600 \\
\hline Virginia & 766 & 153 & 1100 \\
\hline Washington & 111 & 62 & 625 \\
\hline West Virginia & 103 & 21 & 1075 \\
\hline Wisconsin & 216 & 20 & 725 \\
\hline Wyoming & 13 & 3 & 650 \\
\hline
\end{tabular}


Table 8-2

CENTRAL AIR CONDITIONER ANNLAL COMPRESSOR BOURS OR OPERATION AT $75^{\circ}$ SET POINI REDUCBD TO $80^{\circ}$ FRaY 5:00 a.m. to 4:00 p.m.

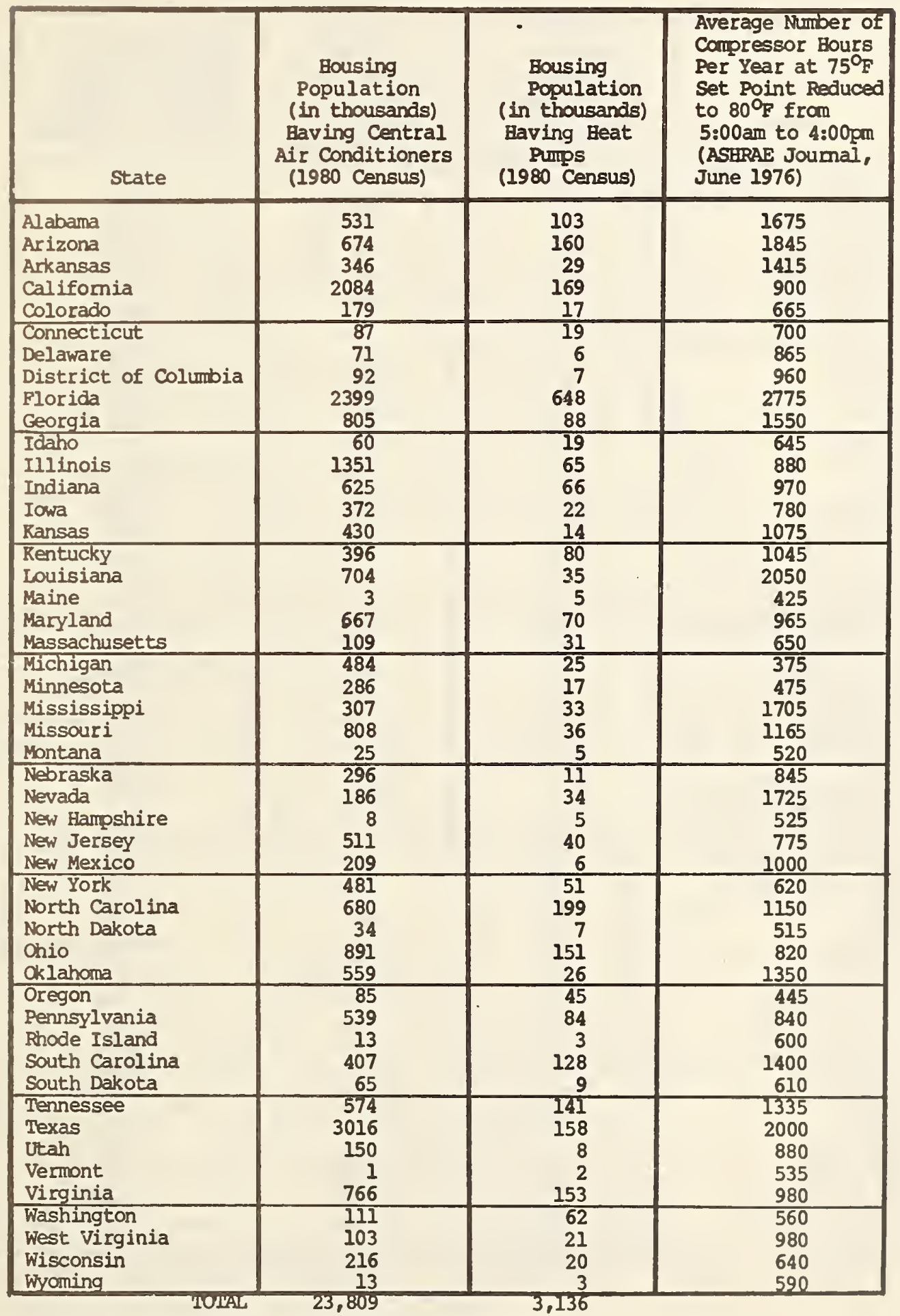


Table 8-3

CDNIRAL ATR CONDITIONER MNULAL CONPRESSOR BOURS OF OBERATION AT 78\% BET ROINT

\begin{tabular}{|c|c|c|c|}
\hline State & $\begin{array}{l}\text { Bousing } \\
\text { population } \\
\text { (In thousands) } \\
\text { Baving Central } \\
\text { Air Conditioners } \\
\text { (1980 Census) }\end{array}$ & $\begin{array}{l}\text { Bousing } \\
\text { Population } \\
\text { (in thousands) } \\
\text { Having Heat } \\
\text { Pumps } \\
\text { (1980 Census) }\end{array}$ & $\begin{array}{l}\text { Average Number of } \\
\text { Compressor Bours } \\
\text { Per Year at } 75^{\circ} \mathrm{F} \\
\text { Set PoInt (ASIRAE } \\
\text { Joumal, June 1976) }\end{array}$ \\
\hline $\begin{array}{l}\text { Alabama } \\
\text { Arizona } \\
\text { Arkansas } \\
\text { California } \\
\text { Colorado }\end{array}$ & $\begin{array}{r}531 \\
674 \\
346 \\
2084 \\
179 \\
\end{array}$ & $\begin{array}{r}103 \\
160 \\
29 \\
169 \\
17\end{array}$ & $\begin{array}{r}1610 \\
1800 \\
1365 \\
1535 \\
750\end{array}$ \\
\hline Connecticut & 87 & $\frac{11}{19}$ & 625 \\
\hline Delaware & 71 & 6 & 785 \\
\hline District of columbia & 92 & 7 & 885 \\
\hline Florida & 2399 & $\begin{array}{r}648 \\
88\end{array}$ & $\begin{array}{l}2375 \\
1675\end{array}$ \\
\hline Georgia & $\frac{805}{60}$ & $\frac{88}{19}$ & $\frac{1615}{575}$ \\
\hline Illinois & 1351 & 65 & $\begin{array}{l}5 / 5 \\
815\end{array}$ \\
\hline Indiana & 625 & 66 & 920 \\
\hline Iowa & 372 & 22 & 725 \\
\hline Ransas & 430 & 14 & 1040 \\
\hline Rentucky & 396 & 80 & 1085 \\
\hline Louisianna & 704 & 35 & 1985 \\
\hline Maine & 3 & 5 & 375 \\
\hline Maryland & 667 & 70 & 890 \\
\hline Massachusetts & 109 & 31 & 540 \\
\hline Michigan & 484 & 25 & 265 \\
\hline Minnesota & .286 & 17 & 465 \\
\hline Mississippi & 307 & 33 & 1625 \\
\hline Missouri & 808 & 36 & 1110 \\
\hline Montana & 25 & 5 & 1390 \\
\hline Nebraska & 296 & 11 & 655 \\
\hline Nevada & 186 & 34 & 1075 \\
\hline New Hampshire & 8 & 5 & 465 \\
\hline New Jersey & 511 & 40 & 700 \\
\hline New Mexico & 209 & 6 & 1300 \\
\hline New York & 481 & 51 & 550 \\
\hline North Carolina & 680 & 199 & 1250 \\
\hline North Dakota & 34 & 7 & 585 \\
\hline Ohio & 891 & 251 & 715 \\
\hline Ok lahoma & 559 & 26 & 1290 \\
\hline Oregon & 85 & 45 & 415 \\
\hline Pennsylvania & 539 & 84 & 525 \\
\hline Rhode Island & 13 & 3 & 325 \\
\hline South Carolina & 407 & 128 & 1225 \\
\hline South Dakota & 65 & 9 & 460 \\
\hline Tennessee & 574 & 141 & 1265 \\
\hline Texas & 3016 & 158 & 1620 \\
\hline Otah & 150 & 8 & 865 \\
\hline Vermont & 1 & 2 & 460 \\
\hline Virginia & 766 & 153 & 885 \\
\hline Washington & III & 62 & 485 \\
\hline West Virginia & 103 & 21 & 900 \\
\hline Wisconsin & 216 & 20 & 370 \\
\hline Wyoming & 13 & 3 & 675 \\
\hline
\end{tabular}


Figure 8-4
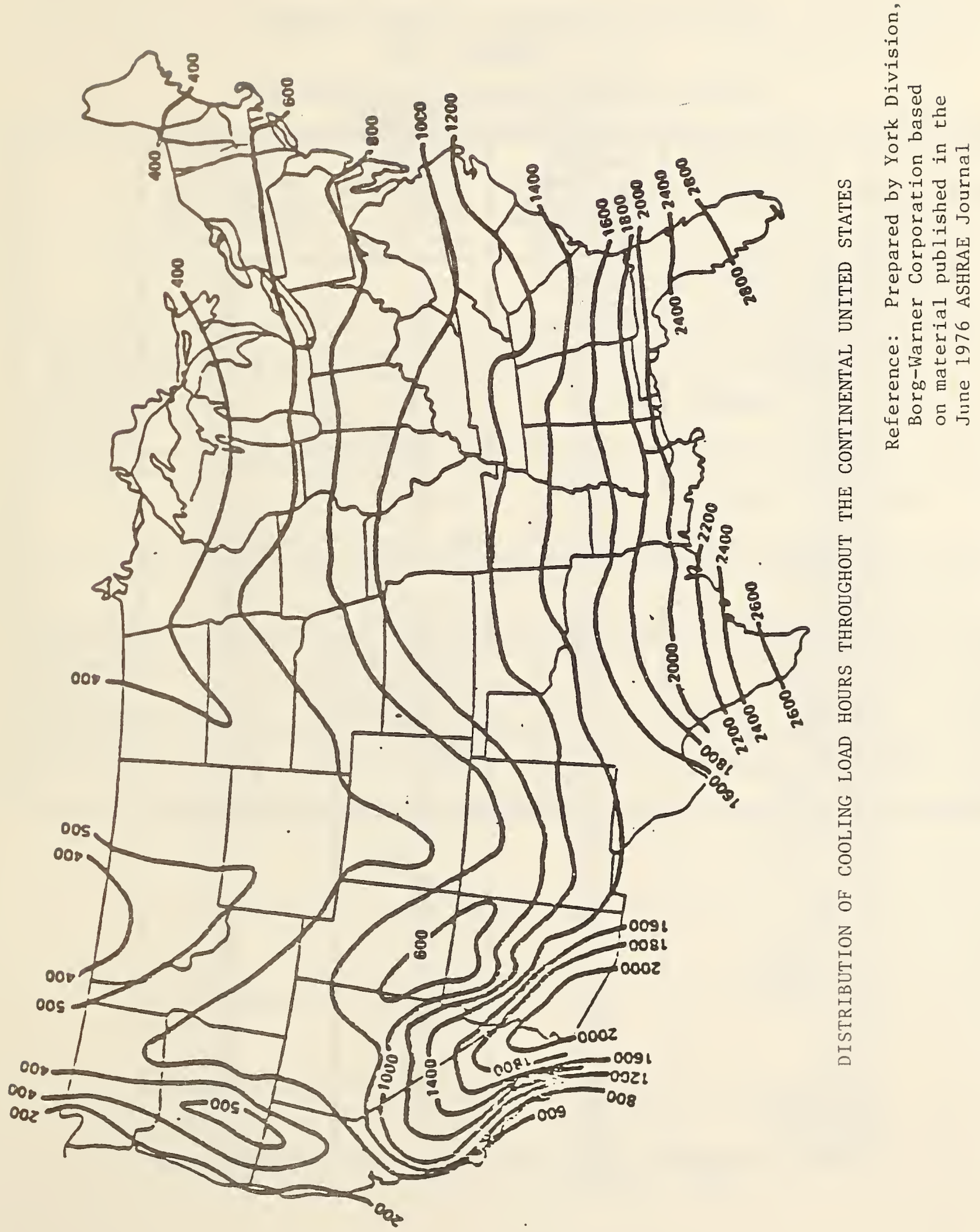

$8-17$ 
Table 8-4

CENITRA AIR CONDITIONIR ANMUAC FUI IOAD COMPRESSOR EOURS OF OPERAIION AT 75\% SEI POINI

\begin{tabular}{|c|c|c|c|}
\hline state & $\begin{array}{l}\text { Bousing } \\
\text { Population } \\
\text { (In thousands) } \\
\text { Baving Central } \\
\text { Alr Conditioners } \\
\text { (1980 Census) }\end{array}$ & $\begin{array}{l}\text { Bousing } \\
\text { Population } \\
\text { (in thousands) } \\
\text { Baving Beat } \\
\text { Pumps } \\
\text { (1980 Census) }\end{array}$ & $\begin{array}{l}\text { Average Number of } \\
\text { Full Load } \\
\text { Compressor Eours } \\
\text { Per Year at } 75^{\circ} \text { F } \\
\text { Set Point (York } \\
\text { Ioad Curve) }\end{array}$ \\
\hline $\begin{array}{l}\text { Alabama } \\
\text { Arizona } \\
\text { Arkansas } \\
\text { California } \\
\text { Colorado } \\
\end{array}$ & $\begin{array}{r}531 \\
674 \\
346 \\
2084 \\
179 \\
\end{array}$ & $\begin{array}{r}103 \\
160 \\
29 \\
169 \\
17\end{array}$ & $\begin{array}{r}1475 \\
1600 \\
1400 \\
900 \\
600 \\
\end{array}$ \\
\hline $\begin{array}{l}\text { Connecticut } \\
\text { Delaware } \\
\text { District of Columbla } \\
\text { Florida } \\
\text { Georgla }\end{array}$ & $\begin{array}{r}87 \\
71 \\
92 \\
2399 \\
805\end{array}$ & $\begin{array}{r}19 \\
6 \\
7 \\
648 \\
88\end{array}$ & $\begin{array}{r}650 \\
800 \\
900 \\
2775 \\
1400\end{array}$ \\
\hline $\begin{array}{l}\text { Idaho } \\
\text { Illinois } \\
\text { Indiana } \\
\text { Iowa } \\
\text { Ransas }\end{array}$ & $\begin{array}{r}60 \\
1351 \\
625 \\
372 \\
430 \\
\end{array}$ & $\begin{array}{l}19 \\
65 \\
66 \\
22 \\
14\end{array}$ & $\begin{array}{r}575 \\
725 \\
875 \\
800 \\
1000 \\
\end{array}$ \\
\hline $\begin{array}{l}\text { Rentucky } \\
\text { Louisianna } \\
\text { Maine } \\
\text { Maryland } \\
\text { Massachusetts } \\
\end{array}$ & $\begin{array}{r}396 \\
704 \\
3 \\
667 \\
109 \\
\end{array}$ & $\begin{array}{r}80 \\
35 \\
5 \\
70 \\
31 \\
\end{array}$ & $\begin{array}{r}950 \\
2000 \\
400 \\
850 \\
550 \\
\end{array}$ \\
\hline $\begin{array}{l}\text { Michigan } \\
\text { Minnesota } \\
\text { Mississippi } \\
\text { Missouri } \\
\text { Montana }\end{array}$ & $\begin{array}{r}-484 \\
286 \\
307 \\
808 \\
25\end{array}$ & $\begin{array}{r}25 \\
17 \\
33 \\
36 \\
5\end{array}$ & $\begin{array}{r}600 \\
500 \\
1650 \\
1100 \\
450 \\
\end{array}$ \\
\hline $\begin{array}{l}\text { Nebraska } \\
\text { Nevada } \\
\text { New Hampshire } \\
\text { New Jersey } \\
\text { New Mexico } \\
\end{array}$ & $\begin{array}{r}296 \\
186 \\
8 \\
511 \\
209 \\
\end{array}$ & $\begin{array}{r}11 \\
34 \\
5 \\
40 \\
6 \\
\end{array}$ & $\begin{array}{r}750 \\
1475 \\
450 \\
750 \\
1000 \\
\end{array}$ \\
\hline $\begin{array}{l}\text { New York } \\
\text { North Carolina } \\
\text { North Dakota } \\
\text { Onio } \\
\text { Oklahoma }\end{array}$ & $\begin{array}{r}481 \\
680 \\
34 \\
891 \\
559\end{array}$ & $\begin{array}{r}51 \\
199 \\
7 \\
151 \\
26 \\
\end{array}$ & $\begin{array}{r}650 \\
1200 \\
400 \\
800 \\
1300 \\
\end{array}$ \\
\hline $\begin{array}{l}\text { Oregon } \\
\text { Pennsylvania } \\
\text { Rhode Island } \\
\text { South Carolina } \\
\text { South Dakota } \\
\end{array}$ & $\begin{array}{r}85 \\
539 \\
13 \\
407 \\
65\end{array}$ & $\begin{array}{r}45 \\
84 \\
3 \\
128 \\
9\end{array}$ & $\begin{array}{r}450 \\
750 \\
600 \\
1325 \\
525 \\
\end{array}$ \\
\hline $\begin{array}{l}\text { Tennessee } \\
\text { Texas } \\
\text { Utah } \\
\text { Vermont } \\
\text { Virginia }\end{array}$ & $\begin{array}{r}574 \\
3016 \\
150 \\
1 \\
766\end{array}$ & $\begin{array}{r}141 \\
158 \\
8 \\
2 \\
153\end{array}$ & $\begin{array}{r}1225 \\
1900 \\
800 \\
500 \\
900\end{array}$ \\
\hline $\begin{array}{l}\text { Washington } \\
\text { West Virginia } \\
\text { Wisconsin } \\
\text { Wyoming }\end{array}$ & $\begin{array}{r}111 \\
103 \\
216 \\
13 \\
\end{array}$ & $\begin{array}{r}62 \\
21 \\
20 \\
3 \\
\end{array}$ & $\begin{array}{l}375 \\
975 \\
550 \\
550 \\
\end{array}$ \\
\hline
\end{tabular}


SUMMARY OF NATIONAL AVERAGE AIR CONDIIIONER ANNUAL COMPRESSOR HOURS

\begin{tabular}{|c|c|c|c|c|}
\hline & & \multicolumn{3}{|c|}{ Annual Hours } \\
\hline & & $\begin{array}{l}\text { Air } \\
\text { Conditioner } \\
\text { Only }\end{array}$ & $\begin{array}{l}\text { Heat } \\
\text { Pump } \\
\text { Only }\end{array}$ & $\begin{array}{c}\text { Total } \\
\text { for Air } \\
\text { Conditioner } \\
\text { and } \\
\text { Heat Pump }\end{array}$ \\
\hline \multirow{3}{*}{$\begin{array}{l}\text { Operating Hours } \\
\text { based on } \\
\text { ASHRAE Journal } \\
\text { June } 1976 \\
\text { and } 1980 \\
\text { Census Data }\end{array}$} & $75^{\circ} \mathrm{F}$ set Point & 1530 & 1684 & 1548 \\
\hline & $\begin{array}{l}{ }^{7} 5^{\circ} \text { Set Point } \\
\left(80^{\circ} \text { from } 5: 00 \text { am }\right. \\
\text { to } 4: 00 \mathrm{pm})\end{array}$ & 1363 & 1499 & 1383 \\
\hline & $78^{\circ} \mathrm{F}$ set Point & 1271 & 1396 & 1286 \\
\hline \multirow{3}{*}{$\begin{array}{l}\text { Full Load } \\
\text { operating } \\
\text { Hours Based } \\
\text { on York } \\
\text { Load Curve } \\
\text { and } 1980 \\
\text { Census Data }\end{array}$} & $75^{\circ} \mathrm{F}$ set Point & 1304 & 1437 & 1319 \\
\hline & $\begin{array}{l}75^{\circ} \mathrm{F} \text { set Point } \\
\left(80^{\circ} \mathrm{F} \text { from } 5: 00 \text { am }\right. \\
\text { to } 4: 00 \text { pm })\end{array}$ & 1161 & 1279 & 1178 \\
\hline & $78^{\circ} \mathrm{F}$ set Point & 1083 & 1196 & 1095 \\
\hline
\end{tabular}


NBS-114A (REV. 2-80)

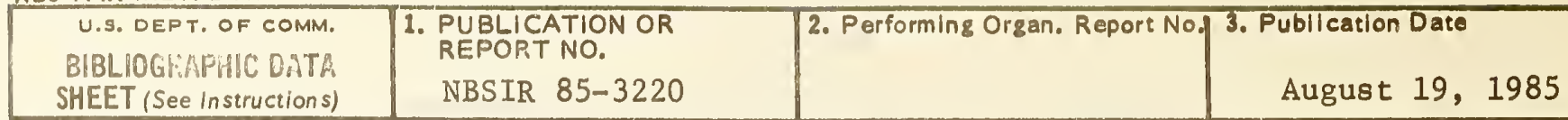

4. TITLE AND SUBTITLE

A Review of Energy Use Factors for Selected Household Appliances

5. AUTHOR(S)

J. Greenberg, B. Reeder, S. Silberstein

6. PERFORMING ORGANIZATION (If joint or other than NBS, see instructions)

NATIONAL BUREAU OF STANDARDS

DEPARTMENT OF COMMERCE

WASHINGTON, D.C. 20234

9. SPONSORHNG ORGANIZATHON NAME AND COMPLETE ADDRESS (Street, CIty, Stote, ZIP)

U.S. Department of Energy

Office of Building Energy Research \& Development

Building Equipment Division

Washington, D.C. 20585

10. SUPPLEMENTARY NOTES

Document describes a computer program; SF-185, FIPS Software Summary, is attached.

11. ABSTRACT (A 200-word or less factual summary of most significont informotion. If document Includes a signlficant bibliography or literature survey. mention it here)

The Energy Policy and Conservation Act (EPCA) as amended by the National Energy Conservation Policy Act (NECPA) requires the development of test procedures, labeling rules, and energy efficiency standards for consumer appliances. These requirements must be established using representative national data when establishing the various parameters for each appliance. During the process of establishing tests procedures, labeling rules, and energy efficiency standards, many of the parametric values used have been questioned through written comment and public hearings. The purpose of this report is to re-evaluate selective parametric values through analysis of current data, and provide comment and recommendations. The parameters reviewed are: For water heaters - inlet water temperature, outlet water temperature, ambient air temperature, and hot water usage; for furnaces - outdoor design temperature and average annual heating hours; for room and central air conditioners - yearly hours of use. Each parameter reviewed is documented in an independent section in this report and indicates the current value, the historical basis for the current value, the approach used to review and update the value, the results and conclusions, and recommendations. The recommendations generally propose a new value for the parameter studied based upon the information analyzed.

12. KEY WORDS (Six to tweive entries; alphabetical order; capitalize only proper names; and separate key words by semicolons) Central Air Conditioner; Furnaces; Hours of Operation; Household Appliance; Hot Water Usage; Outdoor Design Temperature; Water Heater; Water Temperature

13. AVAILABILITY

[X] Unlimited

$\square$ For Officlal Distrlbution. Do Not Release to NTIS

[ Order From Superlntendent of Documents, U.S. Government Printing Office, Washington, D.C. 20402.

[X] Order From National Technical Information Service (NTIS), Springfleid, VA. 2216I
14. NO. OF

PRINTED PAGES

86

15. Price

$\$ 11.50$ 

